\title{
Synthesis and Characterization of A Stable Non-cyclic Bis(amino)arsenium Cation
}

\begin{tabular}{|r|l|}
\hline Journal: & Canadian Journal of Chemistry \\
\hline Manuscript ID & cjc-2017-0420.R1 \\
\hline Danuscript Type: & Article \\
\hline Complete List of Authors: & $\begin{array}{l}\text { Kuprat, Marcus; Universitat Rostock } \\
\text { Schulz, Axel; Universitat Rostock, Chemistry } \\
\text { Thomas, Max; Universitat Rostock } \\
\text { Villinger, Alexander; University of Rostock, Chemistry }\end{array}$ \\
\hline $\begin{array}{r}\text { Is the invited manuscript for } \\
\text { consideration in a Special } \\
\text { Issue?: }\end{array}$ & N Burford \\
\hline Keyword: & arsenic, cation, bis(amino)arsenium cation, crystal structure \\
\hline
\end{tabular}

SCHOLARONE ${ }^{\text {m }}$

Manuscripts 
Abstract:

The reaction of $\mathrm{Li}[\mathrm{Mes} * \mathrm{NH}]\left(\mathbf{1}, \mathrm{Mes} *=2,4,6\right.$-tri-tert-butylphenyl) with aminoarsane $\mathrm{Mes} * \mathrm{~N}(\mathrm{H}) \mathrm{AsCl}_{2}(\mathbf{2}$, $\left.14 \mathrm{Mes}^{*}=2,4,6-t-\mathrm{Bu}_{3} \mathrm{C}_{6} \mathrm{H}_{2}\right)$ at $-80{ }^{\circ} \mathrm{C}$ resulted in the formation of bisamino(chloro)arsane $(\mathrm{Mes} * \mathrm{NH})_{2} \mathrm{AsCl}$ $15(3 \mathrm{Cl})$ by elimination of $\mathrm{LiCl} .3 \mathrm{Cl}$ reacted with the Lewis acids such as $\mathrm{AlCl}_{3}, \mathrm{GaCl}_{3}$ and $\mathrm{Ag}[\mathrm{X}]\left(\mathrm{X}=\mathrm{AsF}_{6}^{-}\right.$, OTf ${ }^{-}, \mathrm{BF}_{4}^{-} ;$OTf $=$trifluoromethanesulfonate $=\mathrm{OSO}_{2} \mathrm{CF}_{3}^{-}$) upon chloride ion abstraction to give salts bearing the cation $\left[\left(\mathrm{Mes}^{*} \mathrm{NH}\right)_{2} \mathrm{As}\right]^{+}\left(3[\mathrm{X}] ; \mathrm{X}=\mathrm{AsF}_{6}{ }^{-}, \mathrm{OTf}^{-}, \mathrm{BF}_{4}^{-}, \mathrm{ECl}_{4} ; \mathrm{E}=\mathrm{Al}, \mathrm{Ga}\right) .3^{+}$represents the first NH-functionalized acyclic bis(amino)arsenium cation. The formation of the salts bearing $\mathbf{3}^{+}$could also be observed in the reaction of cyclo-1,3-diarsa-2,4-diazane $\left[\mathrm{ClAs}(\mu \text {-NMes*) }]_{2}\right.$ (4) with Lewis acids $\left(\mathrm{AlCl}_{3}\right.$, $\mathrm{GaCl}_{3}$ ) in the presence of proton sources in solution. All presented salts $3[\mathrm{X}]$ were stable at room 21 temperature and fully characterized.

Keywords: arsenic, cation, bis(amino)arsenium cation, crystal structure 


\section{Introduction}

In the last decades the possibility to generate dicoordinate nitrogen bound arsenic compounds was shown not only for a series of amino(imino)arsanes (I, Scheme 1) but also for non-cyclic and cyclic bis(amino)arsenium ions (II, III). ${ }^{1-7}$ Furthermore, base stabilized mono ${ }^{8}$ and di cations of arsenic have been reported. ${ }^{9}$

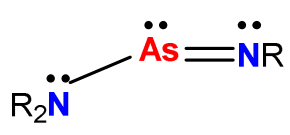

I

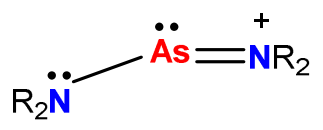

II

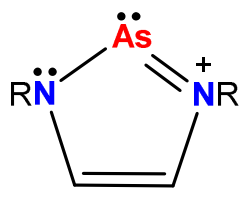

III

Scheme 1. I: aminoiminoarsane, II: bis(amino)arsenium cation, III: $(6 \pi)$-diazarsolium cation.

As depicted in Scheme 2, for acyclic bis(amino)arsenium cations, at least three Lewis representations need to be considered. The second resonance structure in Scheme 2 displays a divalent As atom with an unsaturated cationic (six valence) electron-deficit center and an empty $\mathrm{p}_{\mathrm{z}}$-orbital. That is why in contrast to species I, compounds such as II and III can be regarded as carbene analogues with respect to the isoelectronic situation in the valence shell.

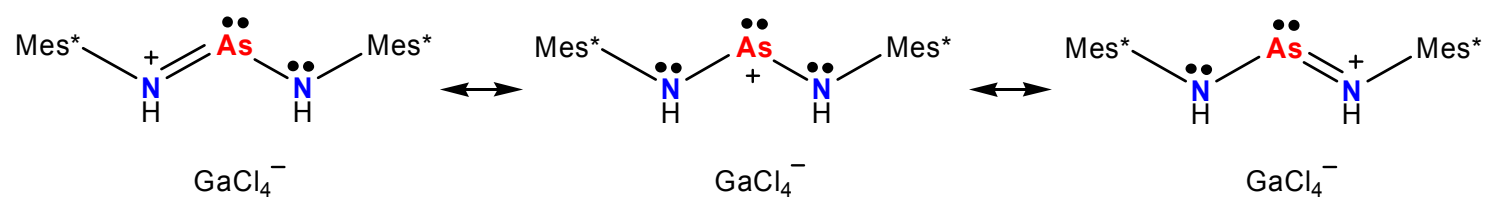

Scheme 2. Resonance structures of acyclic bis(amino)arsenium cations.

While numerous acyclic diaminophosphenium ions are known, ${ }^{10}$ up to now only two structures of salts with an acyclic diaminoarsenium cation $\left[\left(\mathrm{R}_{2} \mathrm{~N}\right)_{2} \mathrm{As}\right]^{+}\left(\mathrm{R}=\mathrm{SiMe}_{3}\right)$ were published in $2013 .^{5}$ Contrarily, cationic four-, five- and six-membered cyclic bis(amino)arsenium salts have been known for years. ${ }^{6,7,11-13}$

The phosphenium ion $\left[\left(\mathrm{Mes}^{*} \mathrm{NH}\right)_{2} \mathrm{P}\right]^{+}$was synthesized by Burford et al. in the reaction of $[\mathrm{Mes} * \mathrm{NP}]^{+}$with Mes $* \mathrm{NH}_{2}$ (supermesityl $=$ Mes* $\left.=2,4,6-t-\mathrm{Bu}_{3} \mathrm{C}_{6} \mathrm{H}_{2}\right) .{ }^{14}$ This reaction was described as a nucleophilic addition of a N-H bond to the phosphadiazonium cation displaying a formal insertion of a NP unit into a N- 
44

45

$\mathrm{H}$ bond. Recently, we could isolate and characterize an arsadiazonium cation [Mes*NAs] $]^{+}$allowing further systematic investigations for the syntheses of dicoordinated arsenium ions $\left[\mathrm{R}_{2} \mathrm{As}\right]^{+} .^{15}$

We describe here the generation of the cation $\left[\left(\mathrm{Mes}^{*} \mathrm{NH}\right)_{2} \mathrm{As}\right]^{+}\left(\mathbf{3}^{+}\right)$as $\left[\mathrm{GaCl}_{4}\right]^{-}$-salt in the reaction of $[\mathrm{Mes} * \mathrm{NAs}]^{+}\left[\mathrm{GaCl}_{4}^{-}\right]\left(\mathbf{5}\left[\mathrm{GaCl}_{4}\right]\right)$ with $\mathrm{Mes}^{*} \mathrm{NH}_{2}$. For the direct syntheses of other salts bearing $\mathbf{3}^{+}$, we present a convenient synthetic protocol starting from $(\mathrm{Mes} * \mathrm{NH})_{2} \mathrm{AsCl}(\mathbf{3 C l})$, which can be considered as an ideal precursor for salts of $\mathbf{3}^{+}$, when treated with chloride ion abstracting Lewis acids. Furthermore, we report on reactions of $\mathrm{Mes}^{*} \mathrm{NAs}^{+}$-salts with Lewis bases such as $\mathrm{PnPh}_{3}(\mathrm{Pn}=\mathrm{P}, \mathrm{As}, \mathrm{Sb})$.

\section{Experimental}

General Information. All manipulations were carried out under oxygen- and moisture-free conditions under argon atmosphere using standard Schlenk or drybox techniques.

Preparation of starting materials. All solvents were freshly distilled prior to use. Methylene dichloride was purified according to a literature procedure, ${ }^{16}$ dried over $\mathrm{P}_{4} \mathrm{O}_{10}$, and distilled from $\mathrm{CaH}_{2}$. Diethylether and toluene were dried over $\mathrm{Na} /$ benzophenone, $n$-hexane was dried over Na/benzophenone/tetraglyme. $N$ butyllithium (2.5M solution in hexanes, Acros Organics) was used as received. $\mathrm{GaCl}_{3}$ (Sigma-Aldrich) was freshly sublimed prior to use. 1,3-Dichloro-2,4-bis-(2,4,6-tri-tert-butylphenyl)cyclo-1,3-diarsa-2,4-diazane $\left[\mathrm{Mes}{ }^{*} \mathrm{NAsCl}\right]_{2}$ (4) was prepared according to a literature procedure. ${ }^{12,15}$ This procedure includes the synthesis of 1. 4-Dimethylaminopyridine (DMAP) was used as received. $\mathrm{PPh}_{3}, \mathrm{AsPh}_{3}$ and $\mathrm{SbPh}_{3}$ were freshly sublimed prior to use.

X-ray: BRUKER Apex Kappa-II CCD diffractometer using graphite monochromated Mo Ka radiation $(\lambda=$ $0.71073)$.

NMR: BRUKER Avance 250, 300 and 500 NMR spectrometers. Spectra were referenced internally to corresponding deuterated solvents $\left({ }^{1} \mathrm{H}: \delta_{\text {ref }}\left(\mathrm{CDHCl}_{2}\right)=5.31 \mathrm{ppm}\right.$, within $\mathrm{CD}_{2} \mathrm{Cl}_{2},{ }^{13} \mathrm{C}: \delta_{\text {ref }}\left(\mathrm{CD}_{2} \mathrm{Cl}_{2}\right)=$ $54 \mathrm{ppm})$.

IR: NICOLET 380 FT-IR spectrometer (Smart Orbit ATR module). 
RAMAN: BRUKER Vertex70 FT-IR with RAM II FT-RAMAN module, Nd:YAG laser (1064 nm) or HORIBA Scientific LabRAM HR800 system, diode laser (785 nm, 100 mW), He-Ne laser (633 nm, 17 $\mathrm{mW})$, frequency doubling $\mathrm{Nd}$ :YAG laser $(532 \mathrm{~nm}, 50 \mathrm{~mW})$.

MS: THERMO ELECTRON Finnigan MAT 95-XP spectrometer.

CHN-Analysis: THERMO QUEST Flash EA 1112 analysator.

Melting points: STANFORD RESEARCH SYSTEMS EZ-Melt, automated analysator, data uncorrected.

Heating rate $20{ }^{\circ} \mathrm{C} / \mathrm{min}$ (clearing-points are reported).

DSC: METTLER-TOLEDO DSC $823 \mathrm{e}$ (Heating rate $5{ }^{\circ} \mathrm{C} / \mathrm{min}$ )

\section{Synthesis of $3 \mathrm{Cl}$}

To a solution of 2,4,6-tri-tert-butylaniline $\left(\mathrm{Mes}^{*} \mathrm{NH}_{2}, 261 \mathrm{mg}, 1.0 \mathrm{mmol}\right)$ in $\mathrm{Et}_{2} \mathrm{O}(10 \mathrm{ml}) n$-Butyllithium $(1.0 \mathrm{mmol})$ is added at room temperature and stirred for 1.5 hours. The reaction solution is added to a stirred solution of $\mathrm{AsCl}_{3}(181 \mathrm{mg}, 1.0 \mathrm{mmol})$ in $\mathrm{Et}_{2} \mathrm{O}(3 \mathrm{ml})$ at room temperature. The resulting rose suspension of generated $\mathrm{Mes}^{*} \mathrm{~N}(\mathrm{H}) \mathrm{AsCl}_{2}$ and $\mathrm{LiCl}$ is stirred for 30 minutes. The precipitated $\mathrm{LiCl}$ is separated by filtration. Li[Mes*NH], obtained from reaction of $\mathrm{Mes}^{*} \mathrm{NH}_{2},(261 \mathrm{mg}, 1.0 \mathrm{mmol})$ and $n$-Butyllithium $(1.0 \mathrm{mmol})$ in $\mathrm{Et}_{2} \mathrm{O}(3 \mathrm{ml})$, is added to the filtrate at $-80^{\circ} \mathrm{C}$ over a period of 10 minutes. The solvent is removed in vacuo at room temperature and the product extracted with $5 \mathrm{ml} n$-hexane. $3 \mathrm{Cl}$ is purified by recrystallization from $\mathrm{Et}_{2} \mathrm{O}$ solution. Decomp. $115^{\circ} \mathrm{C}$. Anal. calc. \% (found) for $\mathrm{C}_{36} \mathrm{H}_{60} \mathrm{AsClN}_{2}$ (631.25): C, 68.50 (66.28); H, 9.58 (9.17); N, 4.44 (4.41). ${ }^{1} \mathrm{H}$ NMR $\left(25^{\circ} \mathrm{C}, \mathrm{CD}_{2} \mathrm{Cl}_{2}, 300.13 \mathrm{MHz}\right): \delta=1.29$ (s, $18 \mathrm{H}, p$ $\left.\mathrm{C}\left(\mathrm{CH}_{3}\right)_{3}\right), 1.53\left(\mathrm{~s}, 36 \mathrm{H}, o-\mathrm{C}\left(\mathrm{CH}_{3}\right)_{3}\right), 5.57(\mathrm{~s}, 2 \mathrm{H}, \mathrm{NH}), 7.33(\mathrm{~s}, 4 \mathrm{H}, \mathrm{CH}) .{ }^{13} \mathrm{C}\left\{{ }^{1} \mathrm{H}\right\} \mathrm{NMR}\left(25^{\circ} \mathrm{C}, \mathrm{CD}_{2} \mathrm{Cl}_{2}\right.$, $75.48 \mathrm{MHz}): \delta=31.76\left(\mathrm{~s}, p-\mathrm{C}\left(\mathrm{CH}_{3}\right)_{3}\right), 33.89\left(\mathrm{~s}, o-\mathrm{C}\left(\mathrm{CH}_{3}\right)_{3}\right), 35.04\left(\mathrm{~s}, p-C\left(\mathrm{CH}_{3}\right)_{3}\right), 36.74\left(\mathrm{~s}, o-C\left(\mathrm{CH}_{3}\right)_{3}\right)$, 124.04 (s, CH, Ar), 137.88 (s, p-Ar), 144.59 (s, o-Ar), 145.32 (s, ipso-Ar). IR (ATR, 64 scans, cm ${ }^{-1}$ ): 3352 (m), 2959 (s), 2951 (s), 2903 (m), 2868 (m), 1597 (m), 1477 (m), 1463 (m), 1422 (s), 1392 (m), 1361 (s), $1304(\mathrm{w}), 1288(\mathrm{~m}), 1241(\mathrm{~m}), 1214(\mathrm{~s}), 1200(\mathrm{~m}), 1111(\mathrm{~s}), 1022(\mathrm{w}), 933(\mathrm{w}), 922(\mathrm{w}), 912(\mathrm{w}), 878(\mathrm{~m})$, $828(\mathrm{~s}), 816(\mathrm{~m}), 780(\mathrm{~m}), 750(\mathrm{~m}), 732(\mathrm{w}), 667(\mathrm{w}), 649(\mathrm{w}), 629(\mathrm{~m}), 594(\mathrm{~m}), 568(\mathrm{w}), 546(\mathrm{w})$. Raman (460 mW, $25^{\circ} \mathrm{C}, 150$ scans, $\mathrm{cm}^{-1}$ ): 3088 (1), 2965 (10), 2909 (9), 2784 (1), 2712 (2), 1601 (5), 1461 (3), 1449 (4), 1430 (3), 1366 (1), 1345 (1), 1293 (3), 1256 (2), 1245 (2), 1225 (3), 1202 (4), 1183 (3), 1146 (3), 1119 (1), 1029 (1), 934 (3), 926 (3), 826 (4), 803 (1), 755 (2), 635 (2), 573 (3), 477 (1), 373 (2), 323 (1), 263 
96

97

98

99

100

101

102

103

104

105

106

107

108

109

110

111

112

113

114

115

116

117

118

119

120

121

(4), 149 (5), 113 (2), 87 (2). MS (CI pos. Isobutane): 262 [Mes*NH$]^{+}, 334$ [Mes*NAs] $]^{+}, 595$

$\left[(\mathrm{Mes} * \mathrm{NH})_{2} \mathrm{As}\right]^{+}$.

\section{Synthesis of $3\left[\mathrm{AlCl}_{4}\right]$}

A) To a stirred colorless solution of $3 \mathrm{Cl}(0.124 \mathrm{mmol}, 78 \mathrm{mg})$ in toluene $(5 \mathrm{ml})$ powdered $\mathrm{AlCl}_{3}$ $(0.124 \mathrm{mmol}, 17 \mathrm{mg})$ is added at $-80{ }^{\circ} \mathrm{C}$. The color of the resulting solution alters to yellow within a few minutes. The solution is warmed up to ambient temperatures and stirred for two hours resulting in a yellow precipitate and a clear colorless supernatant which is removed by a syringe. The precipitate is washed with toluene and dried in vacuo. $3\left[\mathrm{AlCl}_{4}\right]$ is obtained as a yellow powder $(90 \mathrm{mg}, 0.118 \mathrm{mmol}, 95 \%)$.

B) To a stirred solution of $4,(0.118 \mathrm{mmol}, 87 \mathrm{mg})$ in toluene $(1 \mathrm{ml})$ a solution of $\mathrm{AlCl}_{3}(0.235 \mathrm{mmol}$, $31 \mathrm{mg})$ in toluene $(8 \mathrm{ml})$ is added dropwise at $-80{ }^{\circ} \mathrm{C}$ to give a clear orange solution. Crystals of 3 [ $\mathrm{AlCl}_{4}$ ] are obtained by subsequent removal of solvent at $-70{ }^{\circ} \mathrm{C}$. The supernatant is removed by decantation. $3\left[\mathrm{AlCl}_{4}\right]$ is isolated as a yellow crystalline solid. Decomp. $156^{\circ} \mathrm{C}$. Anal. calc. \% (found) for $\mathrm{C}_{36} \mathrm{H}_{60} \mathrm{AlAsCl}_{4} \mathrm{~N}_{2}$ (764.59): C, 56.55 (56.27); H, 7.91 (7.89); N, 3.66 (3.69). ${ }^{1} \mathrm{H}$ NMR $\left(25^{\circ} \mathrm{C}_{,} \mathrm{CD}_{2} \mathrm{Cl}_{2}\right.$, $250.13 \mathrm{MHz}): \delta=1.32\left(\mathrm{~s}, 18 \mathrm{H}, p-\mathrm{C}\left(\mathrm{CH}_{3}\right)_{3}\right), 1.57\left(\mathrm{~s}, 36 \mathrm{H}, o-\mathrm{C}\left(\mathrm{CH}_{3}\right)_{3}\right), 7.53(\mathrm{~s}, 4 \mathrm{H}, \mathrm{CH}), 10.44(\mathrm{~s}, 2 \mathrm{H}$, $\mathrm{N} H) .{ }^{13} \mathrm{C}\left\{{ }^{1} \mathrm{H}\right\}$ NMR $\left(25^{\circ} \mathrm{C}, \mathrm{CD}_{2} \mathrm{Cl}_{2}, 62.90 \mathrm{MHz}\right): \delta=31.5\left(\mathrm{~s}, p-\mathrm{C}\left(\mathrm{CH}_{3}\right)_{3}\right), 34.6\left(\mathrm{~s}, o-\mathrm{C}\left(\mathrm{CH}_{3}\right)_{3}\right), 35.6(\mathrm{~s}, p-$ $\left.C\left(\mathrm{CH}_{3}\right)_{3}\right), 37.5\left(\mathrm{~s}, o-C\left(\mathrm{CH}_{3}\right)_{3}\right), 124.8$ (s, $\left.\mathrm{CH}, \mathrm{Ar}\right), 131.4$ (s, $p$-Ar), 148.5 (s, o-Ar), 152.5 (s, ipso-Ar). IR (ATR, 64 scans, $\mathrm{cm}^{-1}$ ): 3236 (m), 3009 (w), 2956 (s), 2872 (m), 1600 (m), $1476(\mathrm{~m}), 1463$ (m), 1419 (m), $1395(\mathrm{~m}), 1362$ (m), $1294(\mathrm{w}), 1269$ (m), 1243 (m), 1214 (s), $1181(\mathrm{~m}), 1106(\mathrm{~s}), 1025(\mathrm{w}), 938(\mathrm{w}), 926$ (w), $912(\mathrm{w}), 881(\mathrm{~m}), 852(\mathrm{~s}), 820(\mathrm{w}), 798(\mathrm{w}), 779(\mathrm{w}), 762(\mathrm{w}), 666(\mathrm{w}), 648(\mathrm{w}), 634(\mathrm{w}), 627(\mathrm{w}), 582$ (s). Raman (784 nm, lat10X, $25^{\circ} \mathrm{C}, 4 \mathrm{sc} / 60 \mathrm{sec}, \mathrm{cm}^{-1}$ ): 2962 (2), 2929 (2), 2904 (2), 2870 (1), 2780 (1), 2708 (1), 1600 (3), 1468 (2), 1454 (2), 1422 (2), 1396 (1), 1363 (1), 1347 (2), 1289 (2), 1254 (1), 1243 (1), 1218 (4), 1186 (5), 1146 (4), 1117 (2), 1024 (1), 927 (2), 861 (10), 821 (6), 798 (5), 762 (3), 698 (4), 648

(2), 569 (3), 465 (2), 418 (1), 349 (3), 263 (2), 183 (2), 134 (6), 119 (6), 107 (7), 70 (10). MS (CI pos. Isobutane): $206\left[\mathrm{Mes}^{*} \mathrm{NH}_{3}-{ }^{t} \mathrm{Bu}\right]^{+}, 262\left[\mathrm{Mes}^{*} \mathrm{NH}_{3}\right]^{+}$. Crystals of 3[ $\left.\mathrm{AlCl}_{4}\right]$ suitable for X-ray crystallographic analysis are obtained by re-crystallization from $\mathrm{CH}_{2} \mathrm{Cl}_{2}$.

\section{Synthesis of 3[GaCl$]$}

https://mc06.manuscriptcentral.com/cjc-pubs 
122

123

124

125

126

127

128

129

130

131

132

133

134

135

136

137

138

139

140

141

142

143

144

145

146

147

148

A) To a stirred solution of $3 \mathrm{Cl}(0.182 \mathrm{mmol}, 115 \mathrm{mg})$ in toluene $(3 \mathrm{ml})$ a solution of $\mathrm{GaCl}_{3}(0.182 \mathrm{mmol}$, $32 \mathrm{mg}$ ) in toluene $(2 \mathrm{ml})$ is added dropwise at room temperature and stirred for one hour resulting in a yellow precipitate and a clear colorless supernatant which is removed by a syringe. The precipitate is washed with toluene and dried in vacuo. $3\left[\mathrm{GaCl}_{4}\right]$ is obtained as a yellow powder $(138 \mathrm{mg}, 0.171 \mathrm{mmol}$, $94 \%)$.

B) To a stirred solution of $4(0.087 \mathrm{mmol}, 64 \mathrm{mg})$ in toluene $(2 \mathrm{ml})$ a solution of $\mathrm{GaCl}_{3}(0.173 \mathrm{mmol}$, $31 \mathrm{mg}$ ) in toluene $(1 \mathrm{ml})$ is added dropwise at $-80^{\circ} \mathrm{C}$, followed by dropwise addition of 2,4,6-tri-tertbutylaniline $\left(\mathrm{Mes}^{*} \mathrm{NH}_{2}, 44 \mathrm{mg}, 0.170 \mathrm{mmol}\right)$ in toluene $(2 \mathrm{ml})$. The reaction mixture is warmed to room temperature and stirred for two hours. Removal of solvent, washing with toluene and drying in vacuo yields $3\left[\mathrm{GaCl}_{4}\right]$ as a yellow powder $(65 \mathrm{mg}, 0.081 \mathrm{mmol}, 92 \%)$. Decomp. $135{ }^{\circ} \mathrm{C}$. Anal. calc. \% (found) for $\mathrm{C}_{36} \mathrm{H}_{60} \mathrm{AsCl}_{4} \mathrm{GaN}_{2}$ (807.33): C, 53.56 (52.69); H, 7.49 (7.02); N, 3.47 (3.42). ${ }^{1} \mathrm{H}$ NMR $\left(25^{\circ} \mathrm{C}_{,} \mathrm{CD}_{2} \mathrm{Cl}_{2}\right.$, $300.13 \mathrm{MHz}): \delta=1.32\left(\mathrm{~s}, 18 \mathrm{H}, p-\mathrm{C}\left(\mathrm{CH}_{3}\right)_{3}\right), 1.57\left(\mathrm{~s}, 36 \mathrm{H}, o-\mathrm{C}\left(\mathrm{CH}_{3}\right)_{3}\right), 7.53(\mathrm{~s}, 4 \mathrm{H}, \mathrm{CH}), 10.50(\mathrm{~s}, 2 \mathrm{H}$, $\mathrm{N} H) .{ }^{13} \mathrm{C}\left\{{ }^{1} \mathrm{H}\right\} \operatorname{NMR}\left(25^{\circ} \mathrm{C}, \mathrm{CD}_{2} \mathrm{Cl}_{2}, 75.48 \mathrm{MHz}\right): \delta=31.51\left(\mathrm{~s}, p-\mathrm{C}(\mathrm{CH})_{3}\right), 34.62\left(\mathrm{~s}, o-\mathrm{C}\left(\mathrm{CH}_{3}\right)_{3}\right), 35.63(\mathrm{~s}$, p-C( $\left.\left.\mathrm{CH}_{3}\right)_{3}\right), 37.50\left(\mathrm{~s}, o-C\left(\mathrm{CH}_{3}\right)_{3}\right), 124.80$ (s, $\left.C \mathrm{H}, \mathrm{Ar}\right), 131.42$ (s, $p$-Ar), 148.43 (s, o-Ar), 152.48 (s, ipso-Ar). IR (ATR, 64 scans, $\mathrm{cm}^{-1}$ ): 3231 (m), 3009 (m), 2956 (s), 2872 (m), 1600 (m), 1475 (m), 1471 (m), 1463 (m), $1418(\mathrm{~m}), 1395(\mathrm{~m}), 1362$ (m), 1294 (w), 1269 (w), 1243 (m), 1213 (s), $1180(\mathrm{~m}), 1105$ (s), 1025 (w), $938(w), 926(w), 912(w), 881(\mathrm{~m}), 851(\mathrm{~s}), 820(\mathrm{w}), 798(w), 779(\mathrm{w}), 762(\mathrm{w}), 666(\mathrm{w}), 647(\mathrm{w}), 634(\mathrm{w})$, 627 (w), 581 (m), 543 (w). Raman (460 mW, $25^{\circ} \mathrm{C}, 150$ scans, $\mathrm{cm}^{-1}$ ): 3237 (1), 3129 (1), 3109 (1), 2971 (10), 2911 (9), 2785 (2), 2712 (2), 1603 (7), 1470 (4), 1457 (3), 1451 (3), 1426 (3), 1399 (2), 1366 (2), 1351 (3), 1293 (3), 1256 (2), 1246 (2), 1221 (5), 1189 (8), 1148 (6), 1119 (3), 1030 (1), 930 (3), 865 (9), 824 (7), 801 (5), 782 (1), 764 (3), 701 (4), 651 (2), 573 (4), 469 (1), 421 (1), 350 (6), 265 (2), 155 (2), 132 (5), 114 (4), 111 (4). MS (CI pos. Isobutane): $262\left[\mathrm{Mes}^{*} \mathrm{NH}_{3}\right]^{+}, 334\left[\mathrm{Mes}^{* N A s}\right]^{+}, 595\left[(\mathrm{Mes} * \mathrm{NH})_{2} \mathrm{As}\right]^{+}$. Crystals of $3\left[\mathrm{GaCl}_{4}\right]$ suitable for X-ray crystallographic analysis are obtained by re-crystallization from a $\mathrm{CH}_{2} \mathrm{Cl}_{2}$ solution of $\mathbf{3}\left[\mathrm{GaCl}_{4}\right]$.

\section{Synthesis of $3[\mathrm{OTf}] \cdot$ toluene}

A) To a stirred colorless solution of $3 \mathrm{Cl}(78 \mathrm{mg}, 0.124 \mathrm{mmol})$ in $\mathrm{CH}_{2} \mathrm{Cl}_{2}(5 \mathrm{ml})$ powdered $\mathrm{Ag}[\mathrm{OTf}]$ $(0.124 \mathrm{mmol}, 32 \mathrm{mg})$ is added at $-80{ }^{\circ} \mathrm{C}$. The color of the resulting solution alters to yellow within a few https://mc06.manuscriptcentral.com/cjc-pubs 
149

150

151

152

153

154

155

156

157

158

159

160

161

162

163

164

165

166

167

168

169

170

171

172

173

174

175

minutes. The solution is warmed up to room temperature under stirring within one hour. Afterwards, the solution is stirred for another hour resulting in a colorless precipitate and a clear orange supernatant. After filtration (F4) and removal of the solvent in vacuo 3[OTf] is obtained as a yellow powder (87 mg, 0.117 mmol, $94 \%$ ).

B) To a stirred solution of $4(0.134 \mathrm{mmol}, 99 \mathrm{mg})$ in toluene $(6 \mathrm{ml})$ powdered $\mathrm{Ag}[\mathrm{OTf}](0.284 \mathrm{mmol}$, $73 \mathrm{mg}$ ) is added at $-80^{\circ} \mathrm{C}$. The resulting orange suspension is warmed to room temperature over a period of one hour and is then filtered (F4), resulting in a yellow solution. Subsequent, the solution is cooled to $80{ }^{\circ} \mathrm{C}$ again and a solution of $\mathrm{PPh}_{3}(0.402 \mathrm{mmol}, 105 \mathrm{mg})$ in toluene $(3 \mathrm{ml})$ is added under stirring. The reaction solution is warmed to room temperature and stirred for two hours resulting in a colorless solid and a clear orange supernatant. The solid is separated from the liquid by filtration. The filtrate is concentrated and cooled to $5{ }^{\circ} \mathrm{C}$. Crystals of $3[\mathrm{OTf}] \cdot$ toluene are obtained by storage of the solution at $5{ }^{\circ} \mathrm{C}$ for some hours. Crystals of $\left[\mathrm{Ag}\left(\mathrm{PPh}_{3}\right)_{3}\right][\mathrm{OTf}] \cdot 2 \mathrm{CH}_{2} \mathrm{Cl}_{2}(9)$ suitable for X-ray crystallographic analysis are obtained by recrystallization of the colorless solid from a $\mathrm{CH}_{2} \mathrm{Cl}_{2}$ solution. Decomp. $165^{\circ} \mathrm{C}$. Anal. calc. \% (found) for $\mathrm{C}_{37} \mathrm{H}_{60} \mathrm{AsF}_{3} \mathrm{~N}_{2} \mathrm{O}_{3} \mathrm{~S}$ (744.87): C, 59.66 (56.97); $\mathrm{H}, 8.12$ (7.74); N, 3.76 (3.67). ${ }^{1} \mathrm{H}$ NMR (25 ${ }^{\circ} \mathrm{C}, \mathrm{CD}_{2} \mathrm{Cl}_{2}$, $250.13 \mathrm{MHz}): \delta=1.32\left(\mathrm{~s}, 18 \mathrm{H}, p-\mathrm{C}\left(\mathrm{CH}_{3}\right)_{3}\right), 1.56\left(\mathrm{~s}, 36 \mathrm{H}, o-\mathrm{C}\left(\mathrm{CH}_{3}\right)_{3}\right), 7.52(\mathrm{~s}, 4 \mathrm{H}, \mathrm{CH}), 11.93(\mathrm{~s}, 2 \mathrm{H}$, $\mathrm{N} H) .{ }^{13} \mathrm{C}\left\{{ }^{1} \mathrm{H}\right\} \mathrm{NMR}\left(25^{\circ} \mathrm{C}, \mathrm{CD}_{2} \mathrm{Cl}_{2}, 62.90 \mathrm{MHz}\right): \delta=31.6\left(\mathrm{~s}, p-\mathrm{C}\left(\mathrm{CH}_{3}\right)_{3}\right), 34.3\left(\mathrm{~s}, o-\mathrm{C}\left(\mathrm{CH}_{3}\right)_{3}\right), 35.6(\mathrm{~s}, p-$ $\left.C\left(\mathrm{CH}_{3}\right)_{3}\right), 37.4\left(\mathrm{~s}, o-C\left(\mathrm{CH}_{3}\right)_{3}\right), 124.4$ (s, CH, Ar), 132.4 (s, p-Ar), 148.5 (s, o-Ar), 151.7 (s, ipso-Ar). IR (ATR, 32 scans, $\mathrm{cm}^{-1}$ ): 2958 (s), 2872 (m), 1599 (m), 1478 (w), 1464 (m), 1456 (w), 1435 (w), 1423 (w), 1397 (m), 1362 (m), 1292 (m), 1269 (m), 1242 (m), 1219 (m), 1209 (s), 1162 (m), 1155 (m), 1108 (m), 1022 (s), 930 (w), 914 (w), 880 (m), 855 (m), 806 (m) 757 (w), 707 (w), 633 (s), 574 (m). Raman (784 nm, lat10X, $25^{\circ} \mathrm{C}, 5 \mathrm{sc} / 40 \mathrm{sec}, \mathrm{cm}^{-1}$ ): 3024 (1), 2970 (2), 2911 (2), 2875 (1), 1600 (3), 1473 (1), 1455 (1), 1442 (2), 1425 (3), 1397 (1), 1365 (1), 1345 (1), 1292 (2), 1244 (1), 1221 (4), 1191 (4), 1148 (4), 1120 (2), 1022 (3), 930 (2), 917 (2), 867 (10), 824 (7), 804 (5), 785 (1), 763 (3), 756 (3), 705 (4), 648 (2), 573 (3), 471 (1), 436 (1), 423 (1), 386 (1), 347 (1), 313 (1), 268 (1), 134 (6), 110 (9), 71 (9). MS (CI pos. Isobutane): 206 $\left[\mathrm{Mes}^{*} \mathrm{NH}_{3}-{ }^{t} \mathrm{Bu}\right]^{+}, 244\left[\mathrm{Mes}^{*}-2 \mathrm{H}\right]^{+}, 246\left[\mathrm{Mes}^{*}\right]^{+}, 262\left[\mathrm{Mes}^{*} \mathrm{NH}_{3}\right]^{+}$. Crystals of $\mathbf{3}[\mathrm{OTf}] \cdot$ toluene suitable for X-ray crystallographic analysis are obtained by re-crystallization from toluene. 
176

177

178

179

180

181

182

183

184

185

186

187

188

189

190

191

192

193

194

195

196

197

198

199

200

201

202

\section{Synthesis of $3\left[\mathrm{BF}_{4}\right] \cdot$ toluene}

A) To a stirred colorless solution of $3 \mathrm{Cl}(78 \mathrm{mg}, 0.124 \mathrm{mmol})$ in $\mathrm{CH}_{2} \mathrm{Cl}_{2}(5 \mathrm{ml})$ powdered $\mathrm{Ag}\left[\mathrm{BF}_{4}\right]$ $(0.124 \mathrm{mmol}, 24 \mathrm{mg})$ is added at $-80^{\circ} \mathrm{C}$. The color of the resulting solution alters to yellow within a few minutes. The solution is warmed up to room temperature and stirred for two hours resulting in a colorless precipitate and a clear orange supernatant. After filtration (F4) and removing of solvent in vacuo $3\left[\mathrm{BF}_{4}\right]$ is obtained as an orange liquid. The product can be obtained as a yellow powder from a $n$-hexane solution (77 mg, $0.113 \mathrm{mmol}, 91 \%$ ).

B) To a stirred solution of $4(0.108 \mathrm{mmol}, 80 \mathrm{mg})$ in $\mathrm{CH}_{2} \mathrm{Cl}_{2}(5 \mathrm{ml})$ powdered $\mathrm{Ag}\left[\mathrm{BF}_{4}\right](0.216 \mathrm{mmol}$, $42 \mathrm{mg}$ ) was added at $-80^{\circ} \mathrm{C}$ resulting in a deep red solution that was stirred for 30 minutes. Afterwards the reaction solution was warmed to room temperature at which the color of the solution changed to yellow. The colorless precipitate is separated from the liquid by filtration (F4). Subsequently, the solvent was removed under reduced pressure and the product extracted with $n$-hexane. Mp. $144{ }^{\circ} \mathrm{C}$. Anal. calc. \% (found) for $\mathrm{C}_{36} \mathrm{H}_{60} \mathrm{AsBF}_{4} \mathrm{~N}_{2}$ (682.6): C, 63.34 (62.34); H, 8.86 (8.81); N, 4.10 (4.42). ${ }^{1} \mathrm{H}$ NMR $\left(25^{\circ} \mathrm{C}, \mathrm{CD}_{2} \mathrm{Cl}_{2}, 250.13\right.$ $\mathrm{MHz}): \delta=1.32\left(\mathrm{~s}, 18 \mathrm{H}, p-\mathrm{C}\left(\mathrm{CH}_{3}\right)_{3}\right), 1.55\left(\mathrm{~s}, 36 \mathrm{H}, o-\mathrm{C}\left(\mathrm{CH}_{3}\right)_{3}\right), 7.52(\mathrm{~s}, 4 \mathrm{H}, \mathrm{CH}), 11.21(\mathrm{~s}, 2 \mathrm{H}, \mathrm{NH})$. ${ }^{11} \mathrm{~B}\left\{{ }^{1} \mathrm{H}\right\} \operatorname{NMR}\left(25^{\circ} \mathrm{C}, \mathrm{CD}_{2} \mathrm{Cl}_{2}, 80.25 \mathrm{MHz}\right): \delta=-0.81 .{ }^{13} \mathrm{C}\left\{{ }^{1} \mathrm{H}\right\} \mathrm{NMR}\left(25^{\circ} \mathrm{C}, \mathrm{CD}_{2} \mathrm{Cl}_{2}, 62.90 \mathrm{MHz}\right): \delta=31.5$ (s, $\left.p-\mathrm{C}\left(\mathrm{CH}_{3}\right)_{3}\right), 34.3\left(\mathrm{~s}, o-\mathrm{C}\left(\mathrm{CH}_{3}\right)_{3}\right), 35.6\left(\mathrm{~s}, p-C\left(\mathrm{CH}_{3}\right)_{3}\right), 37.4\left(\mathrm{~s}, o-C\left(\mathrm{CH}_{3}\right)_{3}\right), 124.5(\mathrm{~s}, C \mathrm{H}, \mathrm{Ar}), 132.1(\mathrm{~s}, p-$ Ar), 148.5 (s, o-Ar), 151.9 (s, ipso-Ar). IR (ATR, 32 scans, $\mathrm{cm}^{-1}$ ): 3232 (m), 3162 (m), 3007 (m), 2960 (s), 2910 (m), 2872 (m), 1596 (m), 1477 (m), 1471 (m), 1464 (m), 1456 (w), $1435(\mathrm{w}), 1421(\mathrm{~m}), 1397$ (m), $1363(\mathrm{~m}), 1288(\mathrm{w}), 1269(\mathrm{w}), 1241(\mathrm{~m}), 1211(\mathrm{~m}), 1180(\mathrm{~m}), 1134(\mathrm{~s}), 1104(\mathrm{~s}), 1070(\mathrm{~s}), 1028(\mathrm{w}), 941$ (s), $913(\mathrm{~m}), 883(\mathrm{~m}), 850(\mathrm{~s}), 819(\mathrm{w}), 784(\mathrm{w}), 759(\mathrm{~m}), 673(\mathrm{~m}), 667(\mathrm{~m}), 648(\mathrm{~m}), 617(\mathrm{w}), 602(\mathrm{w}), 569$ (w). Raman (784 nm, lat10X, $25^{\circ} \mathrm{C}, 6 \mathrm{sc} / 30 \mathrm{sec}, \mathrm{cm}^{-1}$ ): 2974 (1), 2907 (1), 1598 (2), 1468 (1), 1445 (1), 1423 (2), 1398 (1), 1367 (1), 1289 (2), 1243 (1), 1216 (2), 1188 (3), 1144 (3), 1117 (2), 1023 (1), 926 (1), 915 (2), 859 (10), 823 (5), 806 (4), 786 (1), 762 (3), 709 (2), 649 (1), 572 (2), 470 (1), 436 (1), 422 (1), 368 (1), 354 (1), 260 (1), 135 (4), 108 (5), 71 (7). MS (CI pos. Isobutane): $206\left[\mathrm{Mes}^{*} \mathrm{NH}_{3}-{ }^{t} \mathrm{Bu}\right]^{+}, 262$ $\left[\mathrm{Mes} * \mathrm{NH}_{3}\right]^{+}$. Crystals of $3\left[\mathrm{BF}_{4}\right] \cdot$ toluene suitable for X-ray crystallographic analysis are obtained by recrystallization from a toluene solution of $3\left[\mathrm{BF}_{4}\right]$. 
204

205

206

207

208

209

210

211

212

213

214

215

216

217

218

219

220

221

222

223

224

225

226

227

228

229

\section{Synthesis of $3\left[\mathrm{AsF}_{6}\right] \cdot 2 \mathrm{CH}_{2} \mathrm{Cl}_{2}$}

To a stirred solution of $\mathrm{Ag}\left[\mathrm{AsF}_{6}\right](0.55 \mathrm{mmol}, 0.163 \mathrm{~g})$ in $\mathrm{CH}_{2} \mathrm{Cl}_{2}(5 \mathrm{ml})$, a yellow solution of 4 $(0.5 \mathrm{mmol}, 0.370 \mathrm{~g})$ in $\mathrm{CH}_{2} \mathrm{Cl}_{2}(3 \mathrm{ml})$, is added dropwise at $-90{ }^{\circ} \mathrm{C}$ over a period of five minutes. The resulting red suspension is warmed to $-50^{\circ} \mathrm{C}$ over a period of one hour and filtered (F4). The solution is slowly cooled to $-80{ }^{\circ} \mathrm{C}$, resulting in the deposition of orange crystals. The supernatant was removed by decantation and the residue was dried in vacuo which yields $3\left[\mathrm{AsF}_{6}\right] \cdot 2 \mathrm{CH}_{2} \mathrm{Cl}_{2}$ as an orange crystalline solid. Decomp. $127^{\circ} \mathrm{C}$. Anal. calc. \% (found) for $3\left[\mathrm{AsF}_{6}\right] \cdot \mathrm{CH}_{2} \mathrm{Cl}_{2}\left(\mathrm{C}_{37} \mathrm{H}_{62} \mathrm{As}_{2} \mathrm{Cl}_{2} \mathrm{~F}_{6} \mathrm{~N}_{2}\right.$ (869.64): C, 51.10 (51.81); H, 7.19 (7.36); N, 3.22 (3.73). ${ }^{1} \mathrm{H}$ NMR $\left(25^{\circ} \mathrm{C}, \mathrm{CD}_{2} \mathrm{Cl}_{2}, 300.13 \mathrm{MHz}\right): \delta=1.33$ (s, $18 \mathrm{H}, p-$ $\left.\mathrm{C}\left(\mathrm{CH}_{3}\right)_{3}\right), 1.56\left(\mathrm{~s}, 36 \mathrm{H}, o-\mathrm{C}\left(\mathrm{CH}_{3}\right)_{3}\right), 7.53(\mathrm{~s}, 4 \mathrm{H}, m-\mathrm{CH}), 10.49(\mathrm{~s}, 2 \mathrm{H}, \mathrm{N} H) .{ }^{13} \mathrm{C}\left\{{ }^{1} \mathrm{H}\right\}$ NMR $\left(25^{\circ} \mathrm{C}\right.$, $\left.\mathrm{CD}_{2} \mathrm{Cl}_{2}, 75.5 \mathrm{MHz}\right): \delta=31.5\left(\mathrm{~s}, p-\mathrm{C}\left(\mathrm{CH}_{3}\right)_{3}\right), 34.3\left(\mathrm{~s}, o-\mathrm{C}\left(\mathrm{CH}_{3}\right)_{3}\right), 35.6\left(\mathrm{~s}, p-C\left(\mathrm{CH}_{3}\right)_{3}\right), 37.5\left(\mathrm{~s}, o-C\left(\mathrm{CH}_{3}\right)_{3}\right)$, 124.7 (s, CH, Ar), 131.7 (s, p-Ar), 148.6 (s, o-Ar), 152.3 (s, ipso-Ar). ${ }^{19} \mathrm{~F}\left\{{ }^{1} \mathrm{H}\right\}$ NMR $\left(25^{\circ} \mathrm{C}_{,} \mathrm{CD}_{2} \mathrm{Cl}_{2}\right.$, 282.4MHz): $\delta=61$ (s, broad). IR (ATR, 32 scans, $\mathrm{cm}^{-1}$ ): $3272(\mathrm{w}), 2959(\mathrm{~m}), 2873(\mathrm{w}), 1597(\mathrm{w}), 1470$ (w), $1455(\mathrm{w}), 1434(\mathrm{w}), 1417(\mathrm{w}), 1396(\mathrm{w}), 1362(\mathrm{~m}), 1297(\mathrm{w}), 1269(\mathrm{w}), 1242(\mathrm{w}), 1211(\mathrm{~m}), 1178(\mathrm{w})$, $1144(\mathrm{w}), 1104(\mathrm{~m}), 1025(\mathrm{w}), 927(\mathrm{w}), 913(\mathrm{w}), 881(\mathrm{~m}), 854(\mathrm{~m}), 847(\mathrm{~m}), 820(\mathrm{w}), 802(\mathrm{~m}), 787(\mathrm{w}), 762$ (w), 693 (s), 670 (s), 650 (m), 608 (m), 595 (m). Raman $\left(50 \mathrm{~mW}, 25^{\circ} \mathrm{C}, 402\right.$ scans, $\left.\mathrm{cm}^{-1}\right): 2968$ (10), 2913 (10), 2789 (2), 2760 (12), 2714 (2), 1601 (7), 1469 (3), 1448 (4), 1416 (3), 1399 (3), 1367 (2), 1292 (3), 1248 (3), 1224 (7), 1193 (6), 1149 (5), 1121 (2), 1030 (1), 930 (2), 870 (4), 826 (5), 802 (2), 766 (1), 754 (1), 698 (2), 679 (2), 648 (1), 632 (1), 573 (3), 476 (1), 430 (1), 415 (1), 392 (1), 369 (2), 324 (3), 284 (2), 261 (2), 149 (5). MS (FAB+, Cs, 20keV, p-NBA matrix): $262\left[\text { Mes*-NH}_{3}\right]^{+}, 334$ [Mes*-NAs] ${ }^{+}$. Crystals of $3\left[\mathrm{AsF}_{6}\right] \cdot 2 \mathrm{CH}_{2} \mathrm{Cl}_{2}$ suitable for $\mathrm{X}$-ray crystallographic analysis are obtained directly from the reaction solution of $3\left[\mathrm{AsF}_{6}\right]$.

\section{Synthesis of 7}

To a stirred solution of $5(0.216 \mathrm{mmol}, 138 \mathrm{mg})$ in toluene $(5 \mathrm{ml})$ a solution of $\mathrm{SbPh}_{3}(0.216 \mathrm{mmol}, 76 \mathrm{mg})$ in toluene $(3 \mathrm{ml})$ was added dropwise at $-60^{\circ} \mathrm{C}$. The obtained deep red solution was warmed to room temperature. The reaction solution was concentrated under reduced pressure and stored for some hours resulting in the deposition of crystals of $7(110 \mathrm{mg}, 0.188 \mathrm{mmol}, 87 \%) . \mathrm{Mp} .164{ }^{\circ} \mathrm{C}$. Anal. calc. \% (found)

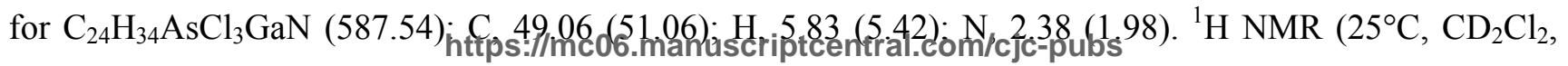


230

231

232

233

234

235

236

237

238

239

240

241

242

243

244

245

246

247

248

249

250

251

252

253

254

255

$300.13 \mathrm{MHz}): \delta=1.33\left(\mathrm{~s}, 9 \mathrm{H}, \mathrm{C} 6\left(\mathrm{CH}_{3}\right)_{3}\right), 1.60\left(\mathrm{~s}, 9 \mathrm{H}, \mathrm{C} 4\left(\mathrm{CH}_{3}\right)_{3}\right), 1.66\left(\mathrm{~s}, 9 \mathrm{H}, \mathrm{C} 2\left(\mathrm{CH}_{3}\right)_{3}\right), 7.39-7.47(\mathrm{~m}, 5$

$\mathrm{H}, \mathrm{Ar}), 7.54(\mathrm{~s}, 2 \mathrm{H}, \mathrm{CH}) .{ }^{13} \mathrm{C}\left\{{ }^{1} \mathrm{H}\right\}$ NMR $\left(25^{\circ} \mathrm{C}, \mathrm{CD}_{2} \mathrm{Cl}_{2}, 75.48 \mathrm{MHz}\right): \delta=31.58\left(\mathrm{C}_{15}\left(\mathrm{CH}_{3}\right)_{3}\right), 33.42$

$\left(\mathrm{C} 4\left(\mathrm{CH}_{3}\right)_{3}\right), 35.27(\mathrm{C} 15), 36.33\left(\mathrm{C} 7\left(\mathrm{CH}_{3}\right)_{3}\right), 37.07(\mathrm{C} 11), 37.98(\mathrm{C} 7), 50.38(\mathrm{C} 6), 125.27$ (C3, C5), 130.05

(p-Ph), $130.99(m-\mathrm{Ph}), 133.54(\mathrm{C} 4), 133.81(o-\mathrm{Ph}), 138.87$ (C19), 146.77 (C2), 149.77 (C1). Due to the high

sensitivity of 7 against air and moisture no effective purification for further analytics of 7 is possible.

Crystals of 7 suitable for X-ray crystallographic analysis can only be obtained directly from the reaction solution of 7 .

\section{Results and Discussion:}

In solution, dimeric $\left[\mathrm{ClAs}\left(\mu-\mathrm{NMes}^{*}\right)\right]_{2}(4)$ readily monomerized to give Mes*NAsCl. The reaction with $\mathrm{GaCl}_{3}$ resulted in the formation of the arsadiazonium salt $[\mathrm{Mes} * \mathrm{~N} \equiv \mathrm{As}]\left[\mathrm{GaCl}_{4}\right]\left(\mathbf{5}\left[\mathrm{GaCl}_{4}\right]\right) .{ }^{15}$ However, in cases of long time storage of $5\left[\mathrm{GaCl}_{4}\right]$ in solutions of toluene or $\mathrm{CH}_{2} \mathrm{Cl}_{2}$ the slow formation of $\left[\left(\mathrm{Mes}^{*} \mathrm{NH}\right)_{2} \mathrm{As}\right]\left[\mathrm{GaCl}_{4}\right]\left(3\left[\mathrm{GaCl}_{4}\right]\right)$ could be observed. A similar reaction sequence was observed when 4 was treated with $\mathrm{AlCl}_{3}$ yielding salt $3\left[\mathrm{AlCl}_{4}\right]$. These results indicated the presence of proton sources e.g. $\mathrm{HCl}$ in solution or the slow generation of protons in these reactions (Scheme 3). Already Burford et al. described the formation of $\left[(\mathrm{Mes} * \mathrm{NH})_{2} \mathrm{P}\right]\left[\mathrm{GaCl}_{4}\right]$ in the reaction of $[\mathrm{Mes} * \mathrm{~N} \equiv \mathrm{P}]\left[\mathrm{GaCl}_{4}\right]$ with $\mathrm{Mes}^{*} \mathrm{NH}_{2}{ }^{14}$ Analogously, we treated $\mathbf{5}\left[\mathrm{GaCl}_{4}\right]$ with $\mathrm{Mes}^{*} \mathrm{NH}_{2}$ affording quantitatively $\mathbf{3}\left[\mathrm{GaCl}_{4}\right]$ (Scheme 3 ). To explain the formation of salts bearing the $\mathbf{3}^{+}$ion starting from $\mathbf{4}$ or $\mathbf{5}^{+}$in the presence of Lewis acids we studied possible proton sources along the synthesis of the starting materials. The generation of starting material 4 was achieved by elimination of $\mathrm{NEt}_{3} \cdot \mathrm{HCl}$ from $\mathrm{Mes}^{*} \mathrm{~N}(\mathrm{H}) \mathrm{AsCl}_{2}(\mathbf{2})$ upon addition of $\mathrm{NEt}_{3}$. Despite several purification steps for $\mathbf{4}$ most likely small amounts of $\mathrm{HCl}$ still remain e.g. as $\mathrm{NEt}_{3} \cdot \mathrm{HCl}$ salt. It is also known that $\mathrm{CH}_{2} \mathrm{Cl}_{2}$ slowly decomposes in the presence of Lewis acids or light generating $\mathrm{HCl}$. Therefore, we believe that storage of dissolved $\mathbf{5}\left[\mathrm{GaCl}_{4}\right]$ for longer periods led to the reaction of $\mathbf{5}^{+}$with two equivalents of $\mathrm{HCl}$ yielding $\mathrm{GaCl}_{3}, \mathrm{AsCl}_{3}$ and $\mathrm{Mes}^{*} \mathrm{NH}_{2}$ which reacted in a subsequent reaction with a further equivalent of

$\mathbf{5}^{+}$to give $3\left[\mathrm{GaCl}_{4}\right]$ (Scheme 3). A similar slow decomposition of 4 can be assumed generating free Mes*NH${ }_{2}$. 

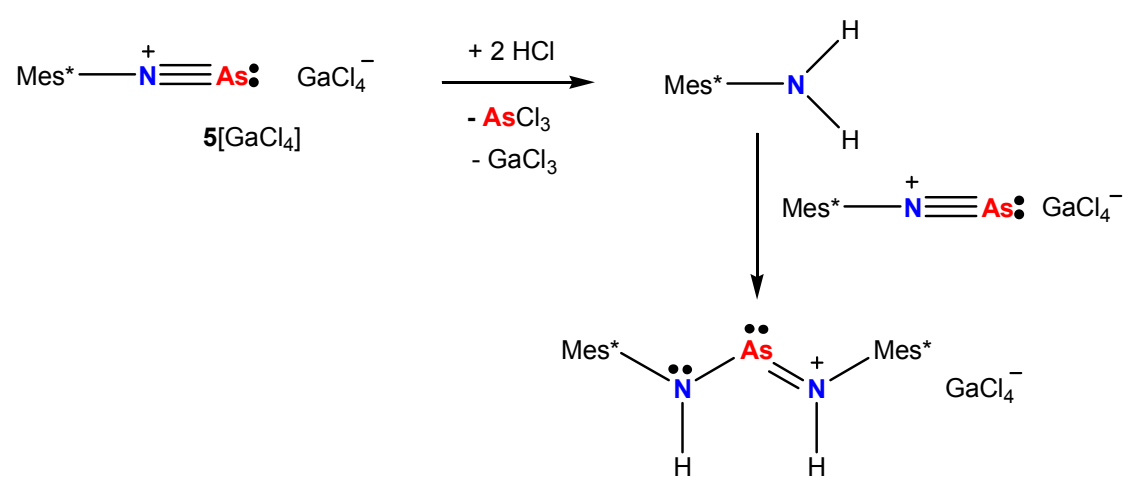

Scheme 3. Proposed reaction pathway of the formation of $3\left[\mathrm{GaCl}_{4}\right]$ in the reaction of $5^{+}$with $\mathrm{HCl}$.

258 $274=\mathrm{Sb}, \mathrm{Bi}) .^{19}$

We have already demonstrated that the chloride abstraction in (TerNH) $)_{2} \mathrm{PCl}$ by Lewis acids such as $\mathrm{GaCl}_{3}$ or several silver salts led to the formation of salts containing the cation $\left[(\mathrm{TerNH})_{2} \mathrm{P}\right]^{+} .{ }^{17}$ Analogously, it was shown by Gudat and co-workers that the reaction of 2-chloro-1,3,2-diazarsolene with $\mathrm{GaCl}_{3}$ gave species III as $\left[\mathrm{GaCl}_{4}\right]^{-}$salt (Scheme $\left.1, \mathrm{R}=\mathrm{Mes}\right){ }^{7}$ During the course of our work we tried to receive salts containing $\mathbf{3}^{+}$ by treatment of $(\mathrm{Mes} * \mathrm{NH})_{2} \mathrm{AsCl}(\mathbf{3 C l})$ with different Lewis acids. Since $\mathbf{3 C l}$ has not been described in literature yet, it was necessary to find first synthetic access to this molecule, which proved to be rather difficult. For this reason, we studied the reaction of $\mathrm{LiN}(\mathrm{H}) \mathrm{Mes}^{*}$ with $\mathrm{AsCl}_{3}$ (Scheme 4). On the basis of ${ }^{1} \mathrm{H}$ NMR spectroscopic data we found that 1 reacted with $\mathrm{AsCl}_{3}$ in a molar ratio of 3:1 at ambient temperature affording deeply red colored crystals of amino(imino)arsane Mes*N(H)AsNMes* (6) and $\mathrm{Mes}^{*} \mathrm{NH}_{2}$ in accord with observations by Lappert et al. in $1986 .^{1}$

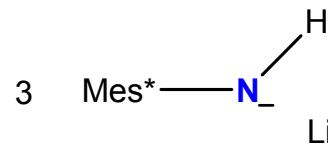

1

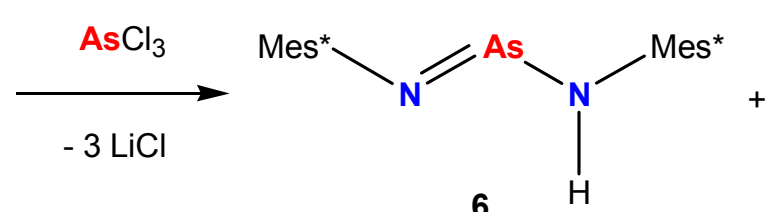

6

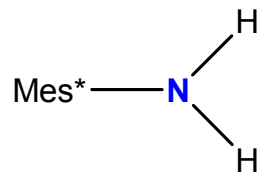

Scheme 4. Reaction of 1 with $\mathrm{AsCl}_{3}$ in a molar ratio of 3:1.

It is noteworthy that Burford et al. obtained the aminoarsane $\mathbf{2}$ in $19 \%$ yield in the reaction of $\mathbf{1}$ with an excess of $\mathrm{AsCl}_{3}$ in $\mathrm{Et}_{2} \mathrm{O}$ at room temperature (Scheme 5). ${ }^{18}$ Interestingly, the reactions of three equivalents of 1 with the heavy $\mathrm{Pn}(\mathrm{III})$-halides resulted in a quantitative amination finally yielding $\mathrm{Pn}\left[\mathrm{N}(\mathrm{H}) \mathrm{Mes}^{*}\right]_{3}(\mathrm{Pn}$ 


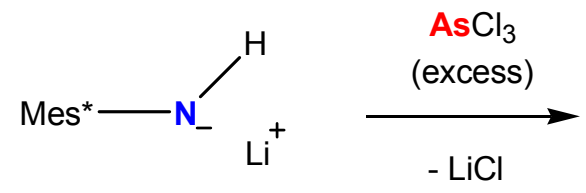

1

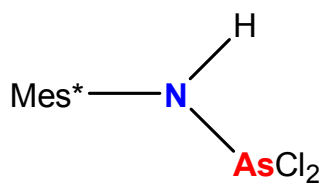

2

276 Scheme 5. Reaction of 1 with an excess of $\mathrm{AsCl}_{3}$ according to Burford et al. ${ }^{18}$

277 The dropwise addition of a solution of $\mathrm{AsCl}_{3}$ to a solution of $\mathrm{Li}[\mathrm{Mes} * \mathrm{NH}]$ (1) in $\mathrm{Et}_{2} \mathrm{O}$ at $278-80{ }^{\circ} \mathrm{C}$ did not only yield 6 and $\mathrm{Mes}^{*} \mathrm{NH}_{2}$ but additionally $3 \mathrm{Cl}$ by elimination of $\mathrm{LiCl}$ (Scheme 6).

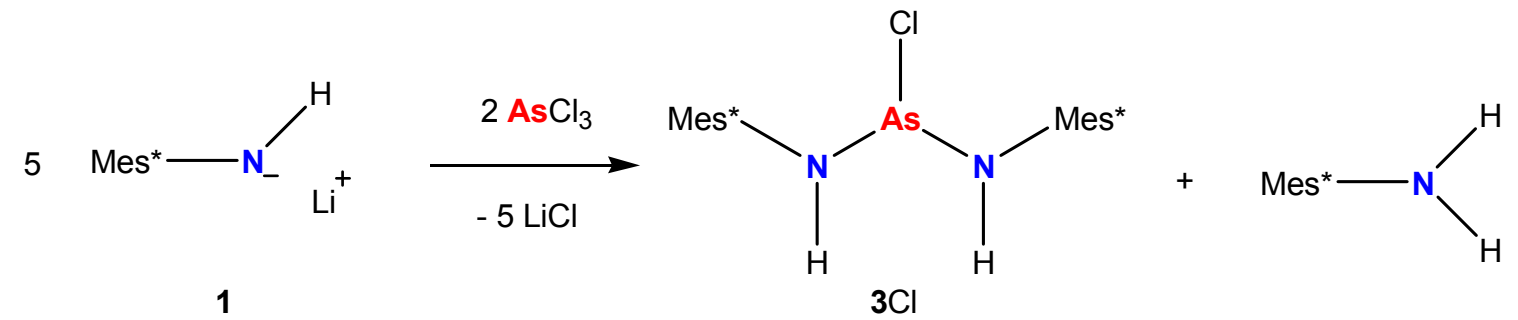

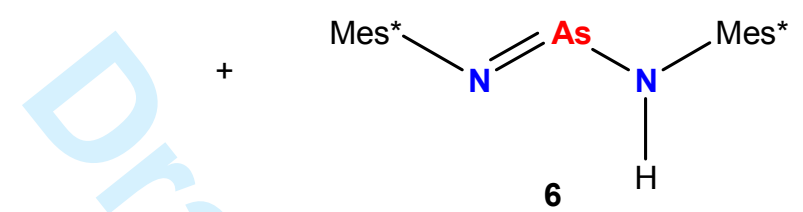

Scheme 6. Observed products for the dropwise addition of $\mathrm{AsCl}_{3}$ to 1 .

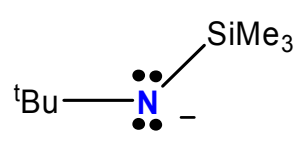

$\mathrm{Li}^{+}$

$-\mathrm{LiCl}$

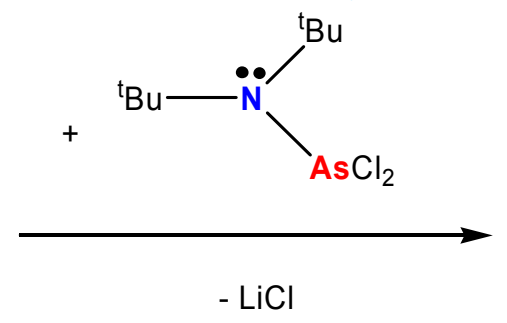

282

On the basis of NMR spectroscopic investigations Scherer et al. reported on the stoichiometric reaction of amino(dichloro)arsane $\mathrm{R}_{2} \mathrm{NAsCl}_{2}$ with $\mathrm{Li}\left[\mathrm{N}(\mathrm{R}) \mathrm{SiMe}_{3}\right]$ which resulted in the formation of the bisamino(chloro)arsane $\mathrm{R}_{2} \mathrm{NAs}(\mathrm{Cl}) \mathrm{N}(\mathrm{R}) \mathrm{SiMe}_{3}\left(\mathrm{R}={ }^{\mathrm{t}} \mathrm{Bu}\right.$ ) (Scheme 7). ${ }^{20}$ Accordingly, in the analogous reaction a solution of $\mathbf{2}$ was added in stoichiometric amounts to a solution of $\mathbf{1}$ in $\mathrm{Et}_{2} \mathrm{O}$ at $-80{ }^{\circ} \mathrm{C}$ ( $\mathrm{Scheme} 8$ ) and pure $3 \mathrm{Cl}$ could be obtained after re-crystallization in rather good yields (ca. $80 \%$ ). 


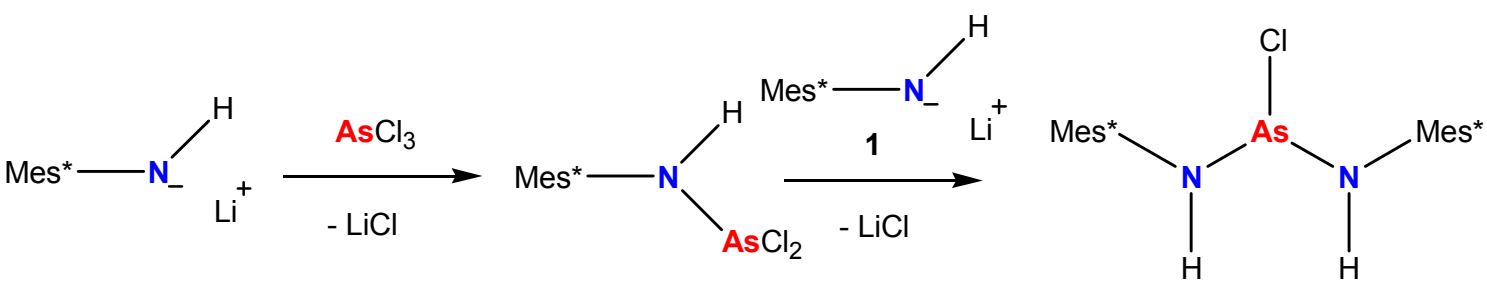
1

2

$3 \mathrm{Cl}$

290

291

292

293

294

295

296

297

298

299

300

Scheme 8. Synthesis of $3 \mathrm{Cl}$ in a two-step synthesis.

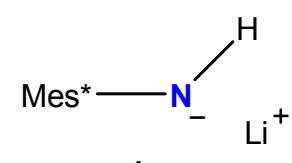

1

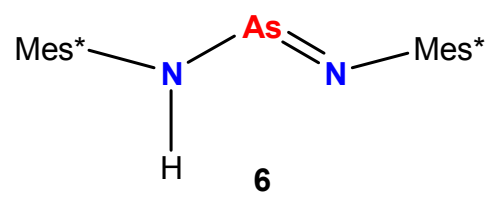

$+\operatorname{Mes}^{*}-\mathrm{N}_{\mathrm{H}}^{\mathrm{H}}$
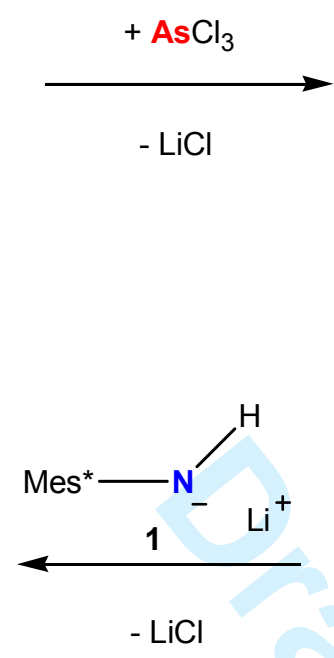

- LiCl
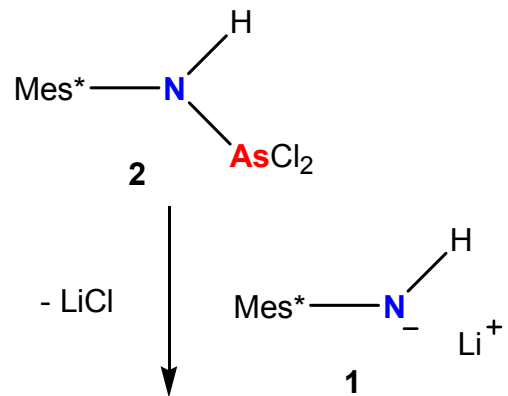

Scheme 9. Reaction pathway for the formation of 6 resulting from the addition of 1 and $\mathrm{AsCl}_{3}$ in a molar ratio of 3:1.

To summarize these results, an excess of $\mathrm{AsCl}_{3}$ resulted in the formation of $\mathbf{2}$, while an excess of $\mathbf{1}$ led to formation of $\mathbf{6}$ and $\mathrm{Mes}^{*} \mathrm{NH}_{2}$ (as shown in Scheme 9). Obviously in the latter case, $\mathbf{1}$ induced upon contact with $3 \mathrm{Cl}$ an indirect "HCl-elimination" in the final step by formation of $\mathrm{LiCl}$ and $\mathrm{Mes}^{*} \mathrm{NH}_{2}$. As a consequence, for a successful generation of $\mathbf{3 C l}$ there had to be neither an excess of $\mathrm{AsCl}_{3}$ nor an excess of $\mathbf{1}$ during the course of reaction. A two-step synthesis as shown in Scheme 8 was found to give the best results.

Subsequently, $3 \mathrm{Cl}$ was treated with the Lewis acids $\mathrm{AlCl}_{3}$ and $\mathrm{GaCl}_{3}$, affording the salts $3\left[\mathrm{AlCl}_{4}\right]$ and $\mathbf{3}\left[\mathrm{GaCl}_{4}\right]$ with yields over $90 \%$. Furthermore, $\mathbf{3 C l}$ was treated with the silver salts $\mathrm{Ag}[\mathrm{OTf}]$ and $\mathrm{Ag}\left[\mathrm{BF}_{4}\right]$ (Scheme 10). After extraction from precipitated silver chloride the solvates 3[OTf] toluene and 
$3033\left[\mathrm{BF}_{4}\right] \cdot$ toluene could be obtained from toluene solution also with yields over $90 \%$. In contrast, the 304 silylaminoarsane $\left[\left(\mathrm{Me}_{3} \mathrm{Si}\right)_{2} \mathrm{~N}\right]_{2} \mathrm{AsCl}$ reacted with $\mathrm{Ag}[\mathrm{OTf}]$ to give the cyclo-1,3-diarsa-2,4-diazane $305\left[\left(\mathrm{Me}_{3} \mathrm{Si}\right)_{2} \mathrm{NAs}-\mu-\mathrm{NSiMe}_{3}\right]_{2}$ by elimination of $\mathrm{Me}_{3} \mathrm{SiOTf}^{5}$ In the reaction of $3 \mathrm{Cl}$ with $\mathrm{Ag}[\mathrm{AsF} 6$, surprisingly 306 a quantitative conversion of $3 \mathrm{Cl}$ to $\mathrm{Mes}^{*} \mathrm{NH}_{2}$ was detected by ${ }^{1} \mathrm{H}$ NMR spectroscopy, presumably due to the 307 presence of HF in solution.
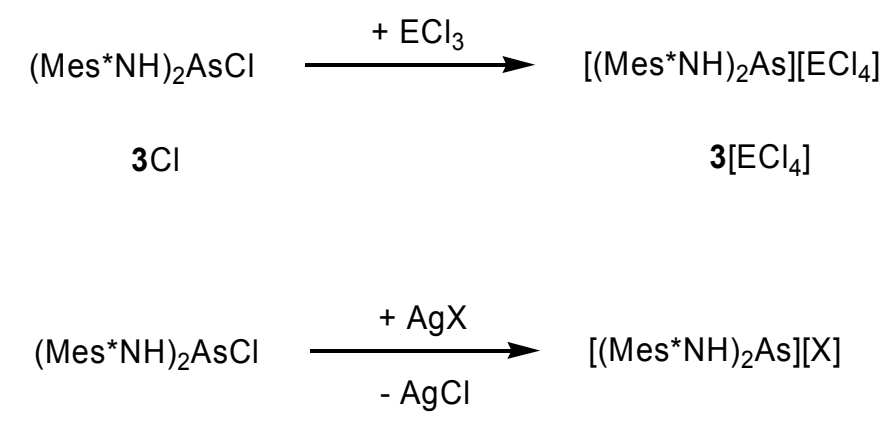

Scheme 10. Top: Reaction of $3 \mathrm{Cl}$ with $\mathrm{ECl}_{3}(\mathrm{E}=\mathrm{Al}, \mathrm{Ga})$. Bottom: Reaction of $3 \mathrm{Cl}$ with $\mathrm{AgX}\left(\mathrm{X}=\mathrm{OTf}^{-}, \mathrm{BF}_{4}{ }^{-}\right)$. towards classical Lewis bases such as pyridine or triphenylpnictanes of the type $\mathrm{PnPh}_{3}(\mathrm{Pn}=\mathrm{P}, \mathrm{As}, \mathrm{Sb})$ and reaction of $5\left[\mathrm{GaCl}_{4}\right]$ with DMAP (4-dimethylaminopyridine) at $-80{ }^{\circ} \mathrm{C}$ yielded monomeric $\mathrm{Mes} * \mathrm{NAsCl}$ and DMAP. $\mathrm{GaCl}_{3}$ adduct. A similar reaction was found when $\mathbf{5}\left[\mathrm{GaCl}_{4}\right]$ was treated with $\mathrm{PPh}_{3}$ at $-80{ }^{\circ} \mathrm{C}$ affording also the chloroiminoarsane along with the $\mathrm{Ph}_{3} \mathrm{P} \cdot \mathrm{GaCl}_{3}$ adduct (Scheme 7). Contrarily, treatment of 5[GaCl$]$ with $\mathrm{AsPh}_{3}$ at $-80{ }^{\circ} \mathrm{C}$ resulted in a product mixture containing also $\mathrm{Mes} * \mathrm{NAsCl}$ and $\mathrm{Ph}_{3} \mathrm{As}^{*} \cdot \mathrm{GaCl}_{3}$ besides arsonium salt $\left[{ }^{t} \mathrm{BuAsPh}_{3}\right]\left[\mathrm{GaCl}_{4}\right] \cdot$ toluene $(\mathbf{8})$ and $3\left[\mathrm{GaCl}_{4}\right]$ which could be co-crystallized both as main products in moderate yields $(\sim 40 \%)$. The formation of an iminodiarsenium salt [Mes*NAsAsPh 3$]\left[\mathrm{GaCl}_{4}\right]$ could not be observed. A further unexpected molecule could be isolated from the reaction of $\mathbf{5}\left[\mathrm{GaCl}_{4}\right]$ with $\mathrm{SbPh}_{3}$ which yielded after formal elimination of $\mathrm{ClSbPh}_{2}$ a four-membered ring with an inner-cyclic As-N-bond, stabilized as $\mathrm{GaCl}_{3}$ adduct (7, Scheme 11). 


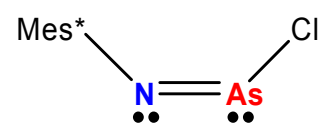

$+$

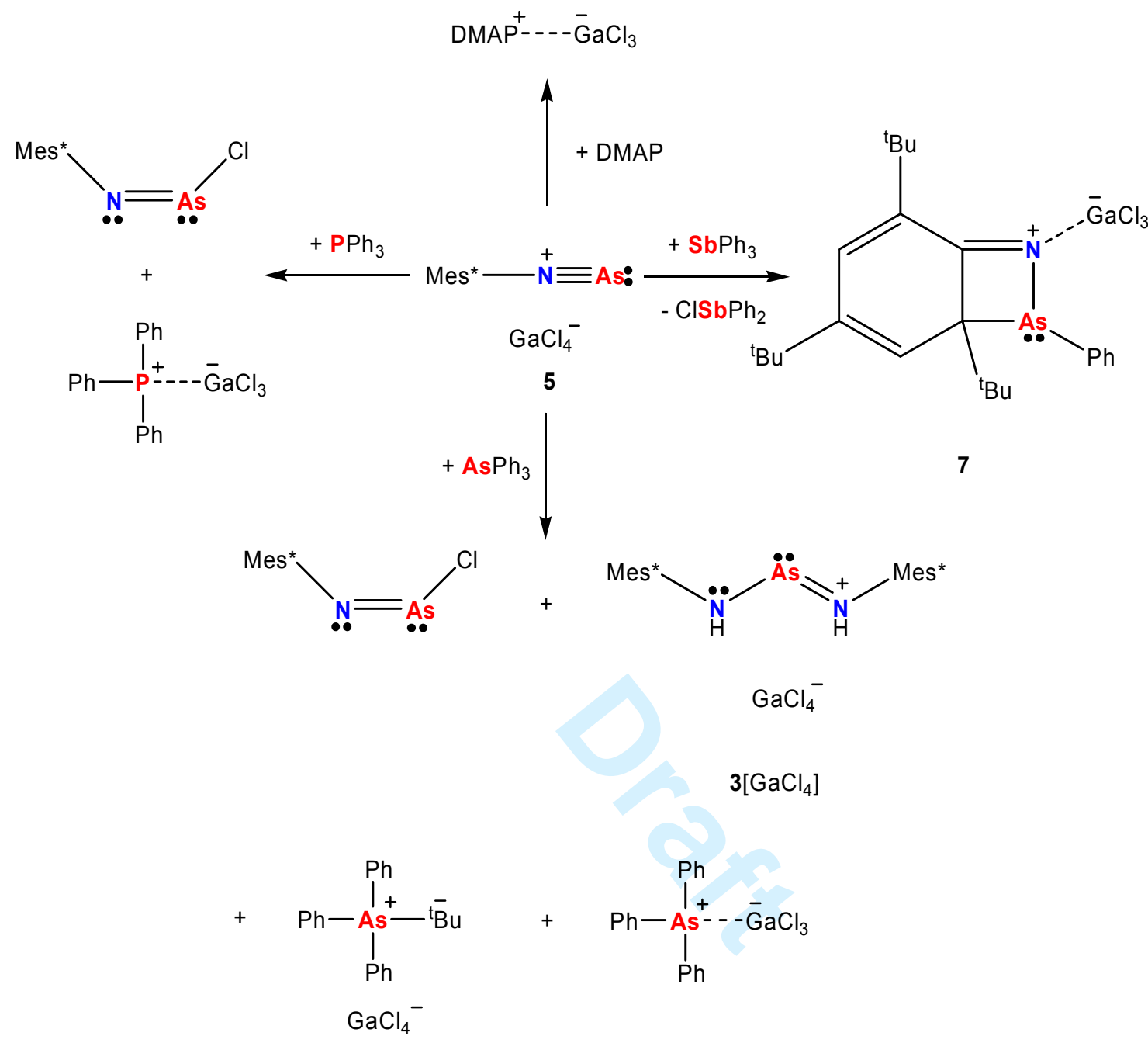

Scheme 11. Summary of the obtained product mixtures in the reactions of $5\left[\mathrm{GaCl}_{4}\right]$ with DMAP and $\mathrm{PnPh}_{3}(\mathrm{Pn}=\mathrm{P}$, As, $\mathrm{Sb})$.

To summarize these findings, on the one hand the stability of the formed adducts by release of one chloride ion from the gallate anion involving the formation of a covalent $\mathrm{As}-\mathrm{Cl}$ bond in $\mathrm{Mes} * \mathrm{NAsCl}$ seemed to be the driving force of the reactions in case of DMAP and $\mathrm{PPh}_{3}$. As already mentioned above, utilization of $5\left[\mathrm{GaCl}_{4}\right]$ also led to the introduction of amounts of $\mathrm{HCl}$ into the reaction systems, which we unfortunately could not avoid. While Mes*NAsCl seemed to be stable in the presence of traces of $\mathrm{HCl}, 5\left[\mathrm{GaCl}_{4}\right]$ 
333 immediately showed decomposition. DMAP. $\mathrm{GaCl}_{3}$ and $\mathrm{Ph}_{3} \mathrm{P} \cdot \mathrm{GaCl}_{3}$ can be regarded as chemically and 334 thermodynamically robust species. In contrast to the latter, adduct formation of $\mathrm{Ph}_{3} \mathrm{As} \cdot \mathrm{GaCl}_{3}$ seemed not to 335 be favored since the formation of several other products were observed at the same time (Scheme 7). In case of $\mathrm{SbPh}_{3}$ formation of $\mathrm{Ph}_{3} \mathrm{Sb} \cdot \mathrm{GaCl}_{3}$ was not observed indicating a smaller Lewis basic character leading to a different reaction channel ( $\mathrm{Ph}$ transfer to arsenic) with the formation of $\mathrm{Ph}_{2} \mathrm{SbCl}$ and 7. On the other hand, it 338 was shown for the chosen reaction systems, that no formation of DMAP adducts of the arsadiazonium ion 339 occurred as well as no formation of phosphinoarsenium or arsinoarsenium ions as observed for the lighter 340 phosphorus congener (Scheme 12). ${ }^{14,24,25}$

341 We also tried to react in situ generated Mes* $\mathrm{NAsCl}$ with $\mathrm{Ag}\left[\mathrm{B}\left(\mathrm{C}_{6} \mathrm{~F}_{5}\right)_{4}\right]$, however, only a complex product 342 mixture was obtained. Thus, we carried out the same reaction in the presence of $\mathrm{SbPh}_{3}$ in the hope to quench $343\left[\mathrm{Mes}^{*} \mathrm{NAs}-\mathrm{SbPh}_{3}\right]^{+}$, which did not work. Again a complex mixture was obtained, from which we were able 344 to crystallize $\left[\mathrm{Ag}\left(\mathrm{SbPh}_{3}\right)_{4}\right]\left[\mathrm{B}\left(\mathrm{C}_{6} \mathrm{~F}_{5}\right)_{4}\right](\mathbf{9})$.
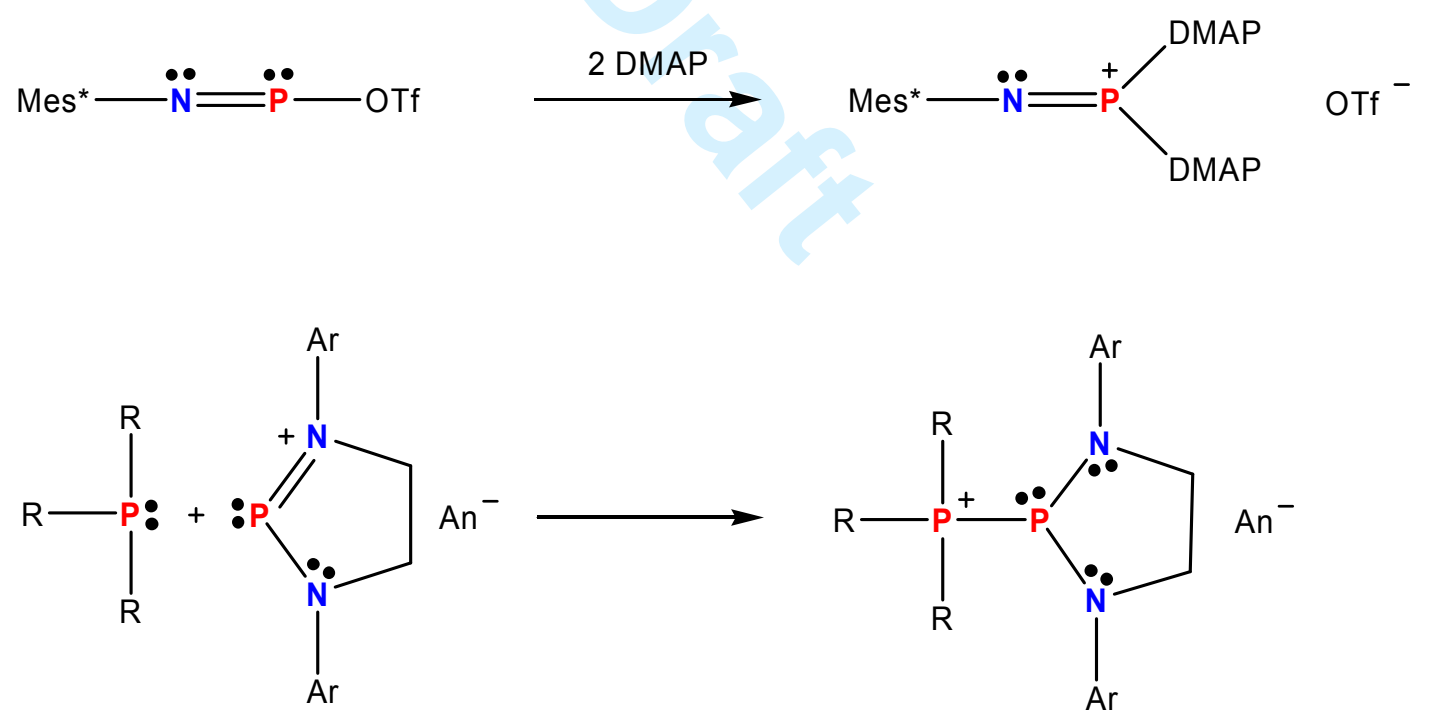

Scheme 12. Top: Reaction of Mes*NPOTf with DMAP reported by Burford et al. ${ }^{24}$ Bottom: Synthesis of a bis(arylamino)phosphinophosphenium salt with $\mathrm{R}=\mathrm{Me}, \mathrm{Ar}=2,6-\left(\mathrm{CHMe}_{2}\right)_{2} \mathrm{C}_{6} \mathrm{H}_{3} ; \mathrm{An}=\mathrm{OTf}^{25}$

Interestingly, when $5\left[\mathrm{GaCl}_{4}\right]$ was treated with $\mathrm{AsPh}_{3}$ at $-80{ }^{\circ} \mathrm{C}$ the beginning formation of the product mixture obviously served as a proton providing medium because of the detected fast formation of $3\left[\mathrm{GaCl}_{4}\right]$ after warming up the reaction solution. For this reaction, a similar reaction sequence as depicted in Scheme 
352

353

354

355

356

357

358

359

360

361

362

363

364

365

366

367

368

369

370

371

372

373

374

375

3 can be assumed. Thus, two general reaction channels for the formation of $3\left[\mathrm{GaCl}_{4}\right]$ are possible with either

$3 \mathrm{Cl}$ or $\mathbf{4}$ as starting materials.

In comparison to the synthesis of $3\left[\mathrm{GaCl}_{4}\right]$ starting from $\mathbf{4}$, the reaction of $\mathbf{4}$ with $\mathrm{Ag}\left[\mathrm{AsF} \mathrm{F}_{6}\right]$ yielded $3\left[\mathrm{AsF}_{6}\right]$. Again small amounts of $\mathrm{HF}$ or $\mathrm{HCl}$ within the reaction system are inevitable. It is known that the reaction of 4 with $\mathrm{Ag}[\mathrm{OTf}]$ resulted in the formation of cyclic $[\mathrm{Mes} * \mathrm{~N}-\mu \text {-AsOTf }]_{2}$ by elimination of silver halide. $^{26}$

Burford et al. explored the electrophilic character of the phosphadiazonium ion $\left[\mathrm{Mes}^{*} \mathrm{~N} \equiv \mathrm{P}\right]^{+}$, e.g. they were able to isolate and fully characterize the iminophosphinphosphonium salt $\left[\mathrm{Mes} * \mathrm{NPPPh}_{3}\right][\mathrm{OTf}]$ obtained when Mes*NPOTf was treated with $\mathrm{PPh}_{3}{ }^{14}$ To compare the reactivity of $\mathbf{5}^{+}$towards $\mathrm{PPh}_{3}$ with the results of the Burford group, additionally, the reaction of $[\mathrm{Mes} * \mathrm{~N}-\mu \text {-AsOTf }]_{2}$ with $\mathrm{PPh}_{3}$ was explored. The main product of this reaction was the formation of $3[\mathrm{OTf}]$ indicating ring-opening upon attack of the base $\mathrm{PPh}_{3}$. As side product, solvated $\left[\mathrm{Ag}\left(\mathrm{PPh}_{3}\right)_{3}\right][\mathrm{OTf}](\mathbf{1 0})$ was isolated in low quantities and fully characterized. Keeping in mind that $[\mathrm{Mes} * \mathrm{~N}-\mu \text {-AsOTf }]_{2}$ was prepared by silver halide elimination it was not surprising that dissolved $\mathrm{Ag}^{+}$salts can easily form solvated $\left[\mathrm{Ag}\left(\mathrm{PPh}_{3}\right)_{3}\right][\mathrm{OTf}]$, which was first described in 2000 by Laguna. $^{27}$

The reaction of 4 with $\mathrm{Ag}\left[\mathrm{BF}_{4}\right]$ proved that among other products the formation of $3\left[\mathrm{BF}_{4}\right]$ also occurred. Scheme 13 summarizes the two general synthetic methods to obtain salts of $\mathbf{3}$, either starting from $\mathbf{3 C l}$ by chloride elimination with Lewis acids (i) or starting from $\mathbf{4}$ in the reaction with Lewis acids in the presence of proton sources (ii).

$\left(\mathrm{Mes}^{*} \mathrm{NH}\right)_{2} \mathrm{AsCl}$

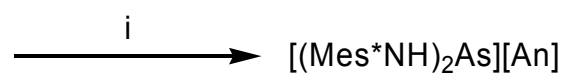

$3 \mathrm{Cl}$
$3[\mathrm{An}]$

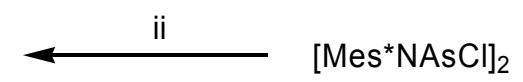

4

Scheme 13. Synthetic methods to obtain salts of 3. Reaction with halides of group 13: (i) $\mathrm{ECl}_{3}, \mathrm{An}=\mathrm{ECl}_{4}, \mathrm{E}=\mathrm{Al}, \mathrm{Ga}$; (ii) $\mathrm{ECl}_{3} / 2 \mathrm{HCl}, \mathrm{An}=\mathrm{ECl}_{4}, \mathrm{E}=\mathrm{Al}, \mathrm{Ga}$. Reaction with silver salts: (i) $\mathrm{Ag}[\mathrm{OTf}], \mathrm{An}=\mathrm{OTf}, \mathrm{Ag}\left[\mathrm{BF}_{4}\right], \mathrm{An}=\mathrm{BF}_{4}$; (ii) 2

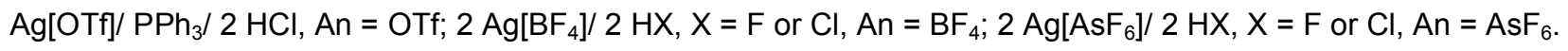


376 Since in case of route (ii) always the formation of product mixtures was found, reaction channel (i) is to be 377 preferred when preparing $\mathbf{3 C l}$. All presented salts of $\mathbf{3}$ were thermally stable and could be stored unlimited at 378 room temperature under inert conditions. They decomposed at temperatures between $127^{\circ} \mathrm{C}$ $379\left(3\left[\mathrm{AsF}_{6}\right] \cdot 2 \mathrm{CH}_{2} \mathrm{Cl}_{2}\right)$ and $165^{\circ} \mathrm{C}(3[\mathrm{OTf}] \cdot$ toluene $)$. The $\mathrm{As}-\mathrm{Cl}$ stretching mode for $3 \mathrm{Cl}$ could be detected in 380 the Raman spectrum at $323 \mathrm{~cm}^{-1}$ (cf. $326 \mathrm{~cm}^{-1}$ for $\left.\left[\left(\mathrm{Me}_{3} \mathrm{Si}\right)_{2} \mathrm{~N}\right]_{2} \mathrm{AsCl}\right)$. A significant feature of all described 381 salts of $\mathbf{3}$ is their pronounced low-field shift of the $\mathrm{N} H$-resonance in the ${ }^{1} \mathrm{H}$ NMR spectra depending of the 382 cationic character. While in $3 \mathrm{Cl}$ a polarized $\mathrm{As}-\mathrm{Cl}$ bond was found $\left(\mathrm{N}-\mathrm{H}: \delta\left[{ }^{1} \mathrm{H}\right]=5.57\right)$, all $\mathbf{3}[\mathrm{X}](\mathrm{X}=$ $383 \mathrm{AlCl}_{4}, \mathrm{GaCl}_{4}, \mathrm{BF}_{4}, \mathrm{OTf}, \mathrm{AsF}_{6}$ ) salts form ion pairs and hence their $\mathrm{N}-H$ resonance was detected in the low384 field range between 10.44 for $3\left[\mathrm{AlCl}_{4}\right]$ and $11.93 \mathrm{ppm}$ for $\mathbf{3}[\mathrm{OTf}]$ (see Table 1). 
386 Table 1: ${ }^{1} \mathrm{H}$ NMR shifts $[\mathrm{ppm}]$ in $\mathrm{CD}_{2} \mathrm{Cl}_{2}$ for $3[\mathrm{X}]\left(\mathrm{X}=\mathrm{AlCl}_{4}, \mathrm{GaCl}_{4}, \mathrm{BF}_{4}, \mathrm{OTf}, \mathrm{AsF}_{6}\right)$ and for comparison $\mathrm{Mes}^{*} \mathrm{NH}_{2}$ and 3872

\begin{tabular}{lcccccccc}
\hline & $\mathbf{3 C l}$ & $\mathbf{3}\left[\mathrm{AlCl}_{4}\right]$ & $\mathbf{3}\left[\mathrm{GaCl}_{4}\right]$ & $\mathbf{3}\left[\mathrm{BF}_{4}\right]$ & $\mathbf{3}[\mathrm{OTf}]$ & $\mathbf{3}\left[\mathrm{AsF}_{6}\right]$ & $\mathrm{Mes}^{*} \mathrm{NH}_{2}$ & $\mathbf{2}$ \\
\hline$p-\mathrm{C}\left(\mathrm{CH}_{3}\right)_{3}$ & 1.29 & 1.32 & 1.32 & 1.32 & 1.32 & 1.33 & 1.27 & 1.28 \\
$o-\mathrm{C}\left(\mathrm{CH}_{3}\right)_{3}$ & 1.53 & 1.57 & 1.57 & 1.55 & 1.56 & 1.56 & 1.45 & 1.49 \\
$\mathrm{CH}, \mathrm{Ar}$ & 7.33 & 7.53 & 7.53 & 7.52 & 7.52 & 7.53 & 7.19 & 7.36 \\
$\mathrm{NH}$ & 5.57 & 10.44 & 10.50 & 11.21 & 11.93 & 10.49 & 4.01 & 5.83 \\
\hline
\end{tabular}

388

389
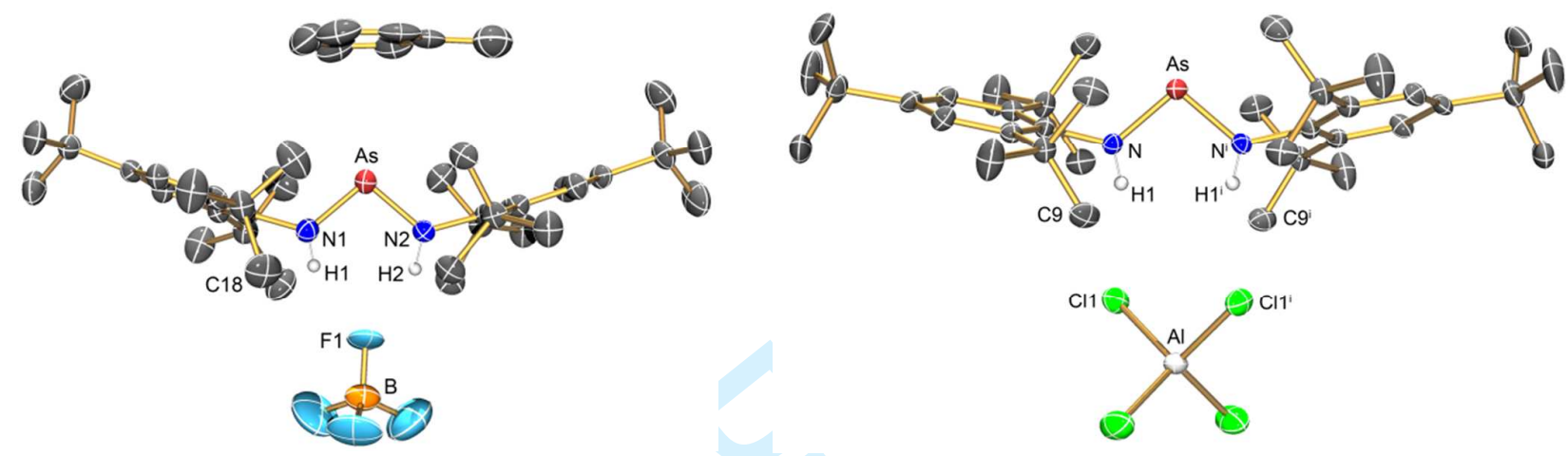

390
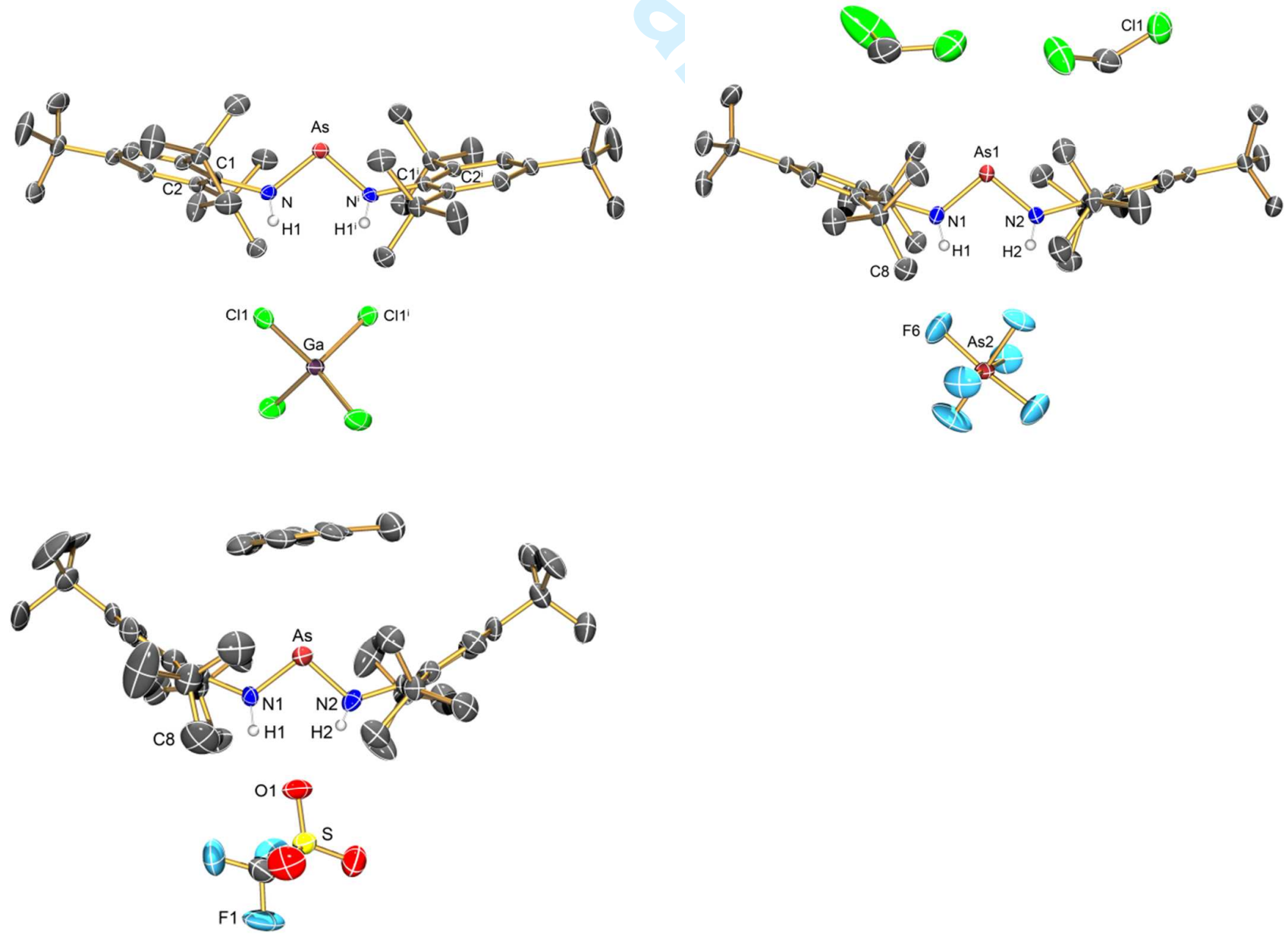

https://mc06.manuscriptcentral.com/cjc-pubs 
392

393

394

395

396

397

398

399

400

401

402

403

404

405

406

407

408

409

410

411

412

413

414

415

416

417

418

Figure 1. ORTEP drawing of the molecular structures of $3[\mathrm{X}]\left(\mathrm{X}=\mathrm{BF}_{4}, \mathrm{AlCl}_{4}, \mathrm{GaCl}_{4}, \mathrm{AsF}_{6}\right.$, OTf) in the crystal. Thermal ellipsoids drawn with $50 \%$ probability at $173 \mathrm{~K}$. Only $\mathrm{N}$-bonded hydrogen atoms are depicted for clarity. Selected bond length and angles are listed in Table 2.

All characterized $\mathbf{3}^{+}$cations (Figure 1) exhibit similar metrical parameters which are summarized in Table 2. The shortest distances between the arsenic centers and the anions are around $3.6 \AA$ in all structures, indicating rather weak cation $\cdots$ anion interactions and similar coordination behavior of all used anions. One of the electronegative atoms of the anion is positioned in such a way that it fits into the pocket formed by the two Mes* substituents directing towards the opened $\mathrm{N}-\mathrm{As}-\mathrm{N}$ unit. Therefore, $\mathrm{N}-\mathrm{H} \cdots \mathrm{X}$ interactions can be assumed. This arrangement and the $\mathrm{N}-\mathrm{H} \cdots \mathrm{X}$ interactions are comparable with those found for the analogous $\left[(\mathrm{TerNH})_{2} \mathrm{P}\right]^{+}$salts. $^{17}$

$\mathbf{3}\left[\mathrm{AlCl}_{4}\right]$ and $\mathbf{3}\left[\mathrm{GaCl}_{4}\right]$ crystallized solvent free, whereas compounds $\mathbf{3}[\mathrm{OTf}], \mathbf{3}\left[\mathrm{BF}_{4}\right]$ and $\mathbf{3}\left[\mathrm{AsF}_{6}\right]$ crystallized as the mono-solvates $\mathbf{3}[\mathrm{OTf}] \cdot$ toluene, $\mathbf{3}\left[\mathrm{BF}_{4}\right] \cdot$ toluene and the di-solvate $\mathbf{3}\left[\mathrm{AsF}_{6}\right] \cdot 2 \mathrm{CH}_{2} \mathrm{Cl}_{2}$. The toluene molecules in $3[\mathrm{OTf}] \cdot$ toluene and $3\left[\mathrm{BF}_{4}\right] \cdot$ toluene adopt comparable positions above the angulated $\mathrm{N}-\mathrm{As}-\mathrm{N}$ unit. It is important to note that in both structures the As centers and the centroids $(\mathrm{Ct})$ of the toluene rings are not arranged on a crystallographic slide axis in the crystal. The shortest distances As $\cdots \mathrm{Ct}$ are $3.161 \AA$ in $3[\mathrm{OTf}] \cdot$ toluene and $3.302 \AA$ in $3\left[\mathrm{BF}_{4}\right] \cdot$ toluene stabilizing these salts by weak interactions $\left(\Sigma r_{\mathrm{vdW}}(\mathrm{As} \cdots \mathrm{C})=3.55 \AA\right) .{ }^{28}$ Moreover, these $\eta^{6}$-interactions confirm the electrophilic character of the As center and pack its coordination sphere so that it is effectively protected against nucleophilic attack what is quite favorable for long-time storage. Such Mentschutkin-type complexes of arsenic halides are already known in the literature. ${ }^{29,30}$

The most prominent structural feature is the bent $\mathrm{N}-\mathrm{As}-\mathrm{N}$ unit $\left(99-100^{\circ}\right)$ with rather short As-N bond lengths between 1.748 and $1.757 \AA$ clearly indicating double bond character $\left(\Sigma r_{\text {cov }}(\mathrm{As}-\mathrm{N})=1.92 \AA\right.$, $\left.\Sigma r_{\text {cov }}(\mathrm{As}=\mathrm{N})=1.74 \AA\right) .{ }^{31}$ The first compound bearing an As=N double bond $(1.714(7)$ and $1.745(7) \AA)$ was $N, N$ '-bis(2,4,6-tri-tert-butylphenyl)amino-iminoarsane, reported by Lappert et al. in $1986 .{ }^{1}$ Moreover cationic diazarsenium $(1.763-1.814 \AA)^{5}$ and neutral tetrazaarsole $(1.784-1.805 \AA)^{32}$ heterocycles containing partial As-N double bonds are known. Recently, neutral triazarsoles heterocycles were synthesized either by insertion of isonitriles into arsatriazanediyls $\left[\operatorname{As}(\mu \text {-NTer })_{2} \mathrm{~N}\right]($ Ter $=2,6$-bis(2,4,6-trimethylphenyl)phenyl, https://mc06.manuscriptcentral.com/cjc-pubs 
$4191.875 \AA)^{33}$ and by making use of a [3+2] cycloaddition reaction between an organic azide and an arsaalkyne $420 \quad(1.839 \AA) .{ }^{34}$

421 Table 2: Selected parameters (distances $[\AA]$, angles [ $\left.{ }^{\circ}\right]$ ) for derivatives of $3[\mathrm{X}]\left(\mathrm{X}=\mathrm{BF}_{4}, \mathrm{AlCl}_{4}, \mathrm{GaCl}_{4}, \mathrm{AsF}_{6}, \mathrm{OTf}\right)$.

\begin{tabular}{llllll}
\hline & $3\left[\mathrm{AlCl}_{4}\right]$ & $3\left[\mathrm{GaCl}_{4}\right]$ & $3[\mathrm{OTf}]$ & $3\left[\mathrm{BF}_{4}\right]$ & $3\left[\mathrm{AsF}_{6}\right]$ \\
\hline $\mathrm{N}-\mathrm{As}\left(^{*}\right)$ & $1.757(3)$ & $1.750(2)$ & $1.760(5)$ & $1.750(3)$ & $1.748(2)$ \\
$\mathrm{C}-\mathrm{N}\left(^{*}\right)$ & $1.453(4)$ & $1.461(3)$ & $1.444(7)$ & $1.453(4)$ & $1.456(3)$ \\
$\mathrm{N}-\mathrm{As}-\mathrm{N}^{*}$ & $99.5(2)$ & $99.6(1)$ & $100.6(2)$ & $99.1(1)$ & $100.0(1)$ \\
$\mathrm{As}-\mathrm{N}-\mathrm{C}\left({ }^{*}\right)$ & $125.1(2)$ & $125.7(2)$ & $119.6(4)$ & $123.9(2)$ & $123.9(2)$ \\
$\Sigma(\Varangle \mathrm{N} 1)$ & 359.1 & 359.5 & 359.1 & 359.7 & 359.6 \\
$\Sigma(\measuredangle \mathrm{N} 2)$ & 359.1 & 359.5 & 360.0 & 360.1 & 360.2 \\
$\mathrm{As}^{+} \ldots \mathrm{X}^{-}$ & 3.633 & 3.624 & 3.539 & 3.637 & 3.659 \\
\hline
\end{tabular}

423 Table 3: Crystallographic details of the structures of $3[\mathrm{X}]\left(\mathrm{X}=\mathrm{BF}_{4}, \mathrm{AlCl}_{4}, \mathrm{GaCl}_{4}, \mathrm{AsF}_{6}\right.$, OTf $)$ and 7.

\begin{tabular}{|c|c|c|c|c|c|c|}
\hline & $3\left[\mathrm{AICl}_{4}\right]$ & $3\left[\mathrm{GaCl}_{4}\right]$ & $3[\mathrm{OTf}] \cdot$ toluene & $3\left[\mathrm{BF}_{4}\right] \cdot$ toluene & $3\left[\mathrm{AsF}_{6}\right] \cdot 2 \mathrm{CH}_{2} \mathrm{Cl}_{2}$ & 7 \\
\hline Chem. Formula & $\mathrm{C}_{36} \mathrm{H}_{60} \mathrm{AlAsCl}_{4} \mathrm{~N}_{2}$ & $\mathrm{C}_{36} \mathrm{H}_{60} \mathrm{AsCl}_{4} \mathrm{GaN}_{2}$ & $\mathrm{C}_{44} \mathrm{H}_{68} \mathrm{AsF}_{3} \mathrm{~N}_{2} \mathrm{O}_{3} \mathrm{~S}$ & $\mathrm{C}_{43} \mathrm{H}_{68} \mathrm{AsBF}_{4} \mathrm{~N}_{2}$ & $\mathrm{C}_{38} \mathrm{H}_{64} \mathrm{As}_{2} \mathrm{Cl}_{4} \mathrm{~F}_{6} \mathrm{~N}_{2}$ & $\mathrm{C}_{24} \mathrm{H}_{34} \mathrm{AsCl}_{3} \mathrm{GaN}$ \\
\hline Form. Wght. [g mol$\left.{ }^{-1}\right]$ & 764.56 & 807.30 & 836.98 & 774.72 & 954.55 & 587.51 \\
\hline Colour & yellow & yellow & yellow & yellow & orange & yellow \\
\hline Cryst. system & monoclinic & monoclinic & orthorhombic & monoclinic & monoclinic & monoclinic \\
\hline Space group & $C 2 / c$ & $C 2 / c$ & $P 2_{1} 2_{1} 2_{1}$ & $P 2_{1} / n$ & $P 2_{1} / n$ & $P 2_{1} / n$ \\
\hline$a[\AA]]$ & $24.945(1)$ & $24.9686(7)$ & $10.6600(5)$ & $10.0267(3)$ & $10.3463(2)$ & $9.7496(3)$ \\
\hline$b[\AA]$ & $10.0767(5)$ & $10.0804(3)$ & $11.4046(5)$ & $24.5792(8)$ & $24.6479(5)$ & $18.9671(5)$ \\
\hline$c[\AA]$ & $16.3057(9)$ & $16.3100(4)$ & $37.459(2)$ & $17.6919(5)$ & $18.1301(4)$ & $14.7660(4)$ \\
\hline$\alpha\left[^{\circ}\right]$ & 90.00 & 90.00 & 90.00 & 90.00 & 90.00 & 90.00 \\
\hline$\beta\left[^{\circ}\right]$ & $93.000(4)$ & $92.793(2)$ & 90.00 & $92.337(2)$ & $92.460(1)$ & $95.991(1)$ \\
\hline$V\left[^{\circ}\right]$ & 90.00 & 90.00 & 90.00 & 90.00 & 90.00 & 90.00 \\
\hline$V\left[\AA^{3}\right]$ & $4093.0(4)$ & $4100.2(2)$ & $4554.0(4)$ & $4356.5(2)$ & $4619.2(2)$ & $2715.6(1)$ \\
\hline Z & 4 & 4 & 4 & 4 & 4 & 4 \\
\hline$\rho_{\text {calc. }}\left[\mathrm{g} \mathrm{cm}^{-3}\right]$ & 1.241 & 1.308 & 1.221 & 1.181 & 1.373 & 1.437 \\
\hline$\mu\left[\mathrm{mm}^{-1}\right]$ & 1.139 & 1.758 & 0.842 & 0.827 & 1.730 & 2.529 \\
\hline$\left.\lambda_{\mathrm{MoK \alpha}}[\AA]\right]$ & 0.71073 & 0.71073 & 0.71073 & 0.71073 & 0.71073 & 0.71073 \\
\hline$T[\mathrm{~K}]$ & $173(2)$ & $173(2)$ & $173(2)$ & 203(2) & $173(2)$ & $173(2)$ \\
\hline Measured reflections & 20489 & 30858 & 35975 & 94859 & 60716 & 68291 \\
\hline $\begin{array}{l}\text { Independent } \\
\text { reflections }\end{array}$ & 4698 & 6248 & 7919 & 10952 & 10606 & 7216 \\
\hline
\end{tabular}




\begin{tabular}{|c|c|c|c|c|c|c|}
\hline $\begin{array}{l}\text { Reflections with } I> \\
2 \sigma(I)\end{array}$ & 2814 & 3942 & 4341 & 6255 & 7346 & 5078 \\
\hline $\mathrm{R}_{\text {int. }}$ & 0.1087 & 0.0802 & 0.1255 & 0.0841 & 0.0364 & 0.0627 \\
\hline$F(000)$ & 1616 & 1688 & 1784 & 1656 & 1976 & 1200 \\
\hline$R_{1}\left(\mathrm{R}\left[F^{2}>2 \sigma\left(F^{2}\right)\right]\right)$ & 0.0532 & 0.0442 & 0.0598 & 0.0603 & 0.0417 & 0.0386 \\
\hline $\mathrm{w} R_{2}\left(F^{2}\right)$ & 0.1162 & 0.0930 & 0.1103 & 0.1278 & 0.1063 & 0.0898 \\
\hline GooF & 1.008 & 0.998 & 1.002 & 1.094 & 1.016 & 1.072 \\
\hline Parameters & 212 & 213 & 510 & 573 & 527 & 280 \\
\hline CCDC \# & 1572163 & 1572160 & 1572161 & 1572162 & 1572159 & 1572157 \\
\hline
\end{tabular}

424

425 


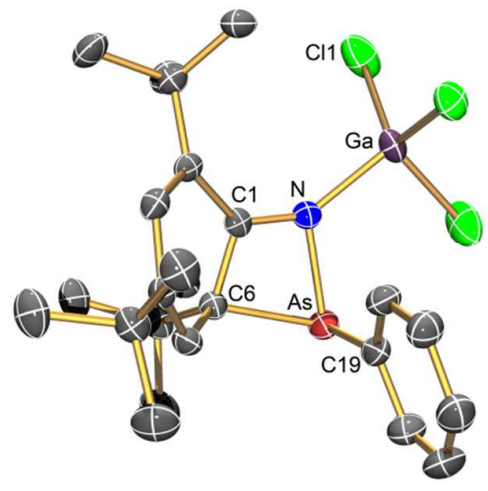

427

428

429

430

431

432

433

434

435

436

437

438

439

440

Figure 2. ORTEP drawing of the molecular structure of $\mathbf{7}$ in the crystal. Thermal ellipsoids drawn with $50 \%$ probability at $173 \mathrm{~K}$. Hydrogen atoms are omitted for clarity. Selected bond length $[\AA]]$ and angles $\left[^{\circ}\right]$ : As-N 1.958(2), N-C1 1.309(3), C1-C6 1.500(3), As-C6 2.038(2), As-C19 1.937(3), N-Ga 1.951(2); N-As-C19 98.5(1), C1-N-Ga 145.5(2), C6-As-N-C1 6.8(1).

7 represents a rare example of a four-membered heterocycle consisting of As, N and two C-atoms (Figure 2). ${ }^{35,36}$ Yellow needles of 7 crystallized in the monoclinic space group $P 2_{1} / n$ with four molecules per unit cell. As depicted in Figure 2, the four-membered ring is almost planar with a maximum deviation from planarity of $6.8^{\circ}(4(\mathrm{C} 6-\mathrm{As}-\mathrm{N}-\mathrm{C} 1))$, while the six-membered condensed ring is stronger distorted from planarity $\left(21.2^{\circ}\right)$. Both rings are arranged almost orthogonally to each other $\left(\Varangle(\mathrm{N}-\mathrm{As}-\mathrm{C} 6-\mathrm{C} 5)=117.6^{\circ}\right)$. The $\mathrm{C} 1-\mathrm{N}$ bond with $1.309(3) \AA$ displays some double bond character $\left(c f . \Sigma r_{\text {cov }}(\mathrm{N}-\mathrm{C})=1.46 \AA, \Sigma r_{\text {cov }}(\mathrm{N}=\mathrm{C})\right.$ $=1.27 \AA),{ }^{31}$ whereas the As-N (1.958(2) $\left.\AA\right)$, As-C6 (2.038(2) $\left.\AA\right)$ and C6-C1 (1.500(3) $\left.\AA\right)$ distances can be regarded as classical single bonds. The Ga-N donor-acceptor bond with 1.951(2) Å lies in the expected range $\left(\Sigma r_{\text {cov }}(\mathrm{N}-\mathrm{Ga})=1.95 \AA\right)^{31}$
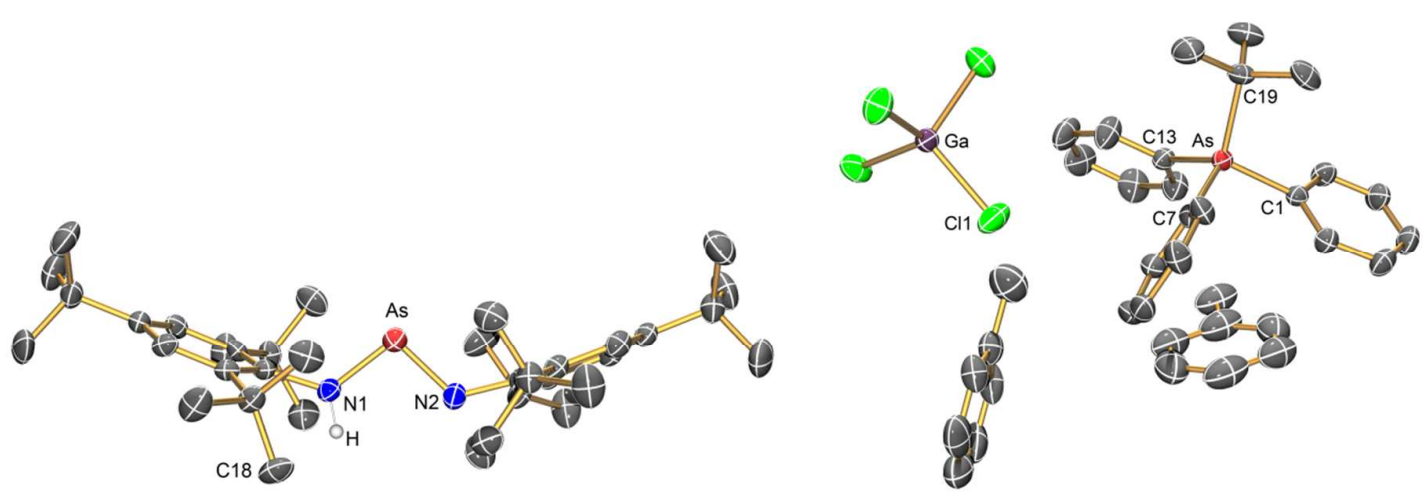
442

443

444

445

446

447

448

449

450

451

452

453

454

455

456

457

458

459

460

Figure 3. ORTEP drawing of the molecular structure of $\mathbf{6}$ and $\mathbf{8}$ in the crystal. Thermal ellipsoids drawn with $50 \%$ probability at $173 \mathrm{~K}$. Hydrogen atoms are omitted for clarity. Selected bond length $\left[\AA \AA\right.$ and angles [ $\left.^{\circ}\right]$ are listed in Tables S8 and Table S10.

Compound 6 crystallized in the orthorhombic space group $P 2{ }_{1} 2_{1} 2_{1}$ with for units per cell (Figure 3). The bent N-As-N $\left(99.0(1)^{\circ}\right)$ moiety displayed rather short N-As bonds (1.733(2), 1.752(2) $\left.\AA\right)$ in accord with the situation found for species $3[\mathrm{X}]$ (vide infra, Table 2). Compound $\mathbf{8}$ crystallized in the triclinic space group $P \overline{1}$ with two formula units per cell (Figure 3). The molecular structure of the cation featured a distorted tetrahedral environment around the central arsenic atom with two distinctly different As- $\mathrm{C}$ bonds $\left(\mathrm{As}-\mathrm{C}_{\mathrm{Ph}}\right.$ 1.911(3)-1.920(3) $\AA$ vs. As $-\mathrm{C}_{\mathrm{tBu}} 1.985(3) \AA$ ). There are no significant cation $\cdots$ anion interactions.
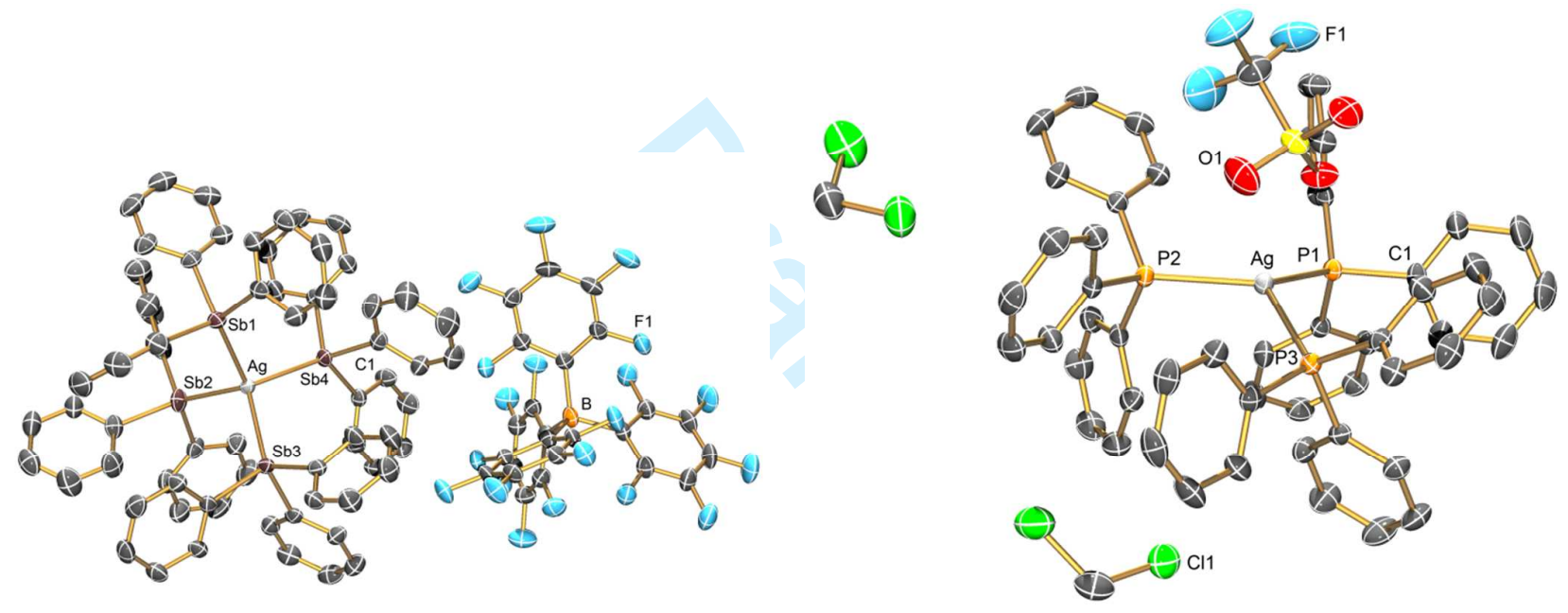

Figure 4. ORTEP drawing of the molecular structure of 9 and 10 in the crystal. Thermal ellipsoids drawn with $50 \%$ probability at $173 \mathrm{~K}$. Hydrogen atoms are omitted for clarity. Selected bond length $[\AA]$ and angles $\left[^{\circ}\right]$ are listed in Tables S11 and Table S12.

Both silver salts $\mathbf{9}$ and $\mathbf{1 0}$ crystallized in the triclinic space group $P \overline{1}$ with two formula units per cell (Figure 4). While 9 displayed a $\mathrm{Ag}^{+}$ion surrounded by four $\mathrm{SbPh}_{3}$ ligands $(\mathrm{Ag}-\mathrm{Sb}$ : between $2.692-2.700 \AA$, $c f$. $\left.\Sigma r_{\text {cov }}(\mathrm{Ag}-\mathrm{Sb})=2.68 \AA\right),{ }^{31}$ thus exhibiting a slightly distorted tetrahedral coordination environment, silver salt 10 is only surrounded by three neutral $\mathrm{PPh}_{3}$ ligands $\left(\mathrm{Ag}-\mathrm{P}\right.$ : between $2.482-2.512 \AA$, $c f . \Sigma r_{\text {cov }}(\mathrm{Ag}-\mathrm{P})=$ 
$4612.39 \AA)^{31}$ but one oxygen atom of the $\mathrm{CF}_{3}-\mathrm{SO}_{3}{ }^{-}$anion is also rather close with 2.657(2) $\AA, c f . \Sigma r_{\text {cov }}(\mathrm{Ag}-\mathrm{O})=$

$4621.91 \AA^{31}$ vs. $\Sigma r_{\mathrm{vdW}}(\mathrm{Ag} \cdots \mathrm{O})=3.24 \AA \AA^{28}$ hence the coordination is best described by a [3+1] mode.

463

464

465 
466

467

468

469

470

471

472

473

474

475

476

477

478

479

480

481

482

483

484

485

486

\section{Conclusion:}

In conclusion, the library of salts with dicoordinated arsenium cations $\left[\mathrm{R}_{2} \mathrm{As}\right]^{+}$has been expanded by a series of acyclic bis(amino)arsenium salts. Additionally, the reactivity of the arsadiazonium ion $[\mathrm{Mes} * \mathrm{~N} \equiv \mathrm{As}]^{+}$towards protons has been explored as well as its Lewis acidic character towards classical Lewis bases such as $\mathrm{PnPh}_{3}(\mathrm{Pn}=\mathrm{P}, \mathrm{As}, \mathrm{Sb})$. A high-yielding synthetic protocols to obtain room temperature stable salts of acyclic $\mathrm{NH}$-functionalized bis(amino)arsenium cation $\left[(\mathrm{Mes} * \mathrm{NH})_{2} \mathrm{As}\right]^{+}$is reported. These new salts represent an interesting building block for the synthesis of low coordinated electrophilic arsenic centers.

\section{TOC Graphic}

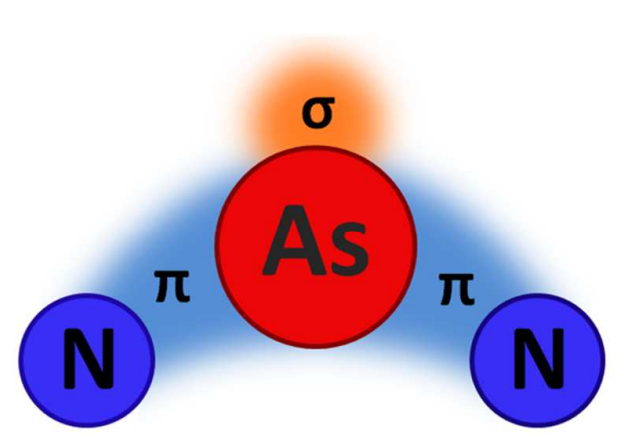

\section{References}

(1) Hitchcock, P. B.; Lappert, M. F.; Rai, A. K.; Williams, H. D. Chem. Commun. 1986, 1633.

(2) Vasisht, S. K.; Sood, M.; Verma, P. K.; Kaur, T.; Usha, K. Phosphorus, Sulfur, and Silicon 1990, 47, 349.

(3) Vasisht, S. K.; Kaur, T. P.; Usha, K.; Kaushal, J.; Bandhu, K. Phosphorus, Sulfur, and Silicon 1995, 107, 189.

(4) Kruppa, C.; Nieger, M.; Ross, B.; Väth, I. Eur. J. Inorg. Chem. 2000, 165. 
487

488

489

490

491

492

493

494

495

496

497

498

499

500

501

502

503

504

505

506

507

508

(5) Hering, C.; Rothe, J.; Schulz, A.; Villinger, A. Inorg. Chem. 2013, 52, 7781.

(6) Carmalt, C. J.; Lomeli, V.; McBurnett, B. G.; Cowley, A. H. Chem. Commun. 1997, 810, 2095.

(7) Gans-Eichler, T.; Gudat, D.; Nieger, M. Heteroat. Chem. 2005, 16, 327.

(8) Spinney, H. A.; Korobkov, I.; DiLabio, G. A.; Yap, G. P. A.; Richeson, D. S. Organometallics 2007, 26,4972 .

(9) Brazeau, A. L.; Nikouline, A. S.; Ragogna, P. J. Chem. Commun. 2011, 47, 4817.

(10) Burford, N.; Losier, P.; Macdonald, C.; Kyrimis, V.; Bakshi, P. K.; Cameron, T. S. Inorg. Chem. 1994, 33, 1434.

(11) Veith, M.; Bertsch, B.; Huch, V. Z. Anorg. Allg. Chem. 1988, 559, 73.

(12) Burford, N.; Landry, J. C.; Ferguson, M. J.; McDonald, R. Inorg. Chem. 2005, 44, 5897.

(13) Payrastre, C.; Madaule, Y.; Wolf, J. G.; Kim, T. C.; Mazières, M.; Wolf, R.; Sanchez, M. Heteroat. Chem. 1992, 3, 157.

(14) Burford, N.; Cameron, T. S.; Clyburne, J. A. C.; Eichele, K.; Robertson, K. N.; Sereda, S.; Wasylishen, R. E.; Whitla, W. A. Inorg. Chem. 1996, 35, 5460.

(15) Kuprat, M.; Schulz, A.; Villinger, A. Angew. Chem., Int. Ed. 2013, 52, 7126.

(16) Fischer, C. B.; Xu, S.; Zipse, H. Chem. Eur. J. 2006, 12, 5779.

(17) Reiß, F.; Schulz, A.; Villinger, A. Eur. J. Inorg. Chem. 2012, 261.

(18) Burford, N.; Cameron, T. S.; Macdonald, C. L. B.; Robertson, K. N.; Schurko, R.; Walsh, D.; McDonald, R.; Wasylishen, R. E. Inorg. Chem. 2005, 44, 8058.

(19) Burford, N.; Macdonald, C. L. B.; Robertson, K. N.; Cameron, T. S. Inorg. Chem. $1996,35,4013$.

(20) Scherer, O. J.; Höntsch, H. Chem. Ber. 1979, 122, 1927.

(21) Burford, N.; Stanley Cameron, T.; Robertson, K. N.; Phillips, A. D.; Jenkins, H. A. Chem. Commun. https://mc06.manuscriptcentral.com/cjc-pubs 
2000, 2087.

510

511

512

513

514

515

516

517

518

519

520

521

522

523

524

525

526

527

528

529

(22) Burford, N.; Phillips, A. D.; Spinney, H. A.; Robertson, K. N.; Cameron, T. S.; McDonald, R. Inorg. Chem. 2003, 42, 4949.

(23) Burford, N.; Cameron, T. S.; Leblanc, D. J.; Phillips, A. D.; Concolino, T. E.; Lam, K.; Rheingold, A. L. J. Am. Chem. Soc. 2000, 122, 5413.

(24) Burford, N.; Spinney, H. A.; Ferguson, M. J.; McDonald, R. Chem. Commun. 2004, 2, 2696.

(25) Abrams, M. B.; Scott, B. L.; Baker, R. T. Organometallics 2000, 19, 4944.

(26) Schulz, A.; Villinger, A. Inorg. Chem. 2009, 48, 7359.

(27) Bardají, M.; Crespo, O.; Laguna, A.; Fischer, A. K. Inorg. Chim. Acta 2000, 304, 7.

(28) Bondi, A. J. Phys. Chem. 1966, 70, 3006.

(29) Schmidbaur, H.; Bublak, W.; Huber, B.; Müller, G. Angew. Chem., Int. Ed. 1987, 26, 234.

(30) Schmidbaur, H.; Schier, A. Organometallics 2008, 27, 2361.

(31) Pyykkö, P.; Atsumi, M. Chem. Eur. J. 2009, 15, 12770.

(32) Schulz, A.; Villinger, A. Angew. Chem., Int. Ed. 2008, 47, 603.

(33) Hinz, A.; Schulz, A.; Villinger, A. Chem. Sci. 2016, 7, 745.

(34) Pfeifer, G.; Papke, M.; Frost, D.; Sklorz, J. A. W.; Habicht, M.; Müller, C. Angew. Chem., Int. Ed. 2016, 55, 11760 .

(35) Grützmacher, H.; Pritzkow, H. Chem. Ber. 1989, 122, 1417.

(36) van den Ancker, T. R.; Andrews, P. C.; King, S. J.; McGrady, J. E.; Raston, C. L.; Roberts, B. A.; Skelton, B. W.; White, A. H. J. Organomet. Chem. 2000, 607, 213. 